\title{
Volcanic ash leaching as a means of tracing the environmental impact of the 2011 Grímsvötn eruption, Iceland
}

\author{
J. Cabré ${ }^{1,2}$, M. Aulinas ${ }^{2}$, M. Rejas ${ }^{1}$, J.L. Fernandez-Turiel ${ }^{1}$ \\ ${ }^{1}$ Institute of Earth Sciences Jaume Almera, ICTJA-CSIC, Lluís Solé i Sabarís \\ s/n, 08028, Barcelona, Spain. e-mail: jlfernandez@ictja.csic.es \\ ${ }^{2}$ Departament de Geoquímica, Petrologia i Prospecció Geològica, Universitat de \\ Barcelona, Martí i Franquès, s/n, 08028, Barcelona, Spain
}

\section{Abstract}

The Grímsvötn volcanic eruption, from 21 to 28 May, 2011, was the largest eruption of the Grímsvötn Volcanic System since 1873, with a Volcanic Explosivity Index (VEI) of magnitude 4. The main geochemical features of the potential environmental impact of the volcanic ash-water interaction were determined using two different leaching methods as proxies (batch and vertical flow-through column experiments). Ash consists of glass with minor amounts of plagioclase, clinopyroxene, diopside, olivine and iron sulfide; this latter mineral phase is very rare in juvenile ash. Ash grain morphology and size reflects the intense interaction of magma and water during eruption. Batch and column leaching tests in deionised water indicate that $\mathrm{Na}, \mathrm{K}, \mathrm{Ca}, \mathrm{Mg}, \mathrm{Si}, \mathrm{Cl}, \mathrm{S}$ and $\mathrm{F}$ had the highest potential geochemical fluxes to the environment. Release of various elements from volcanic ash took place immediately through dissolution of soluble salts from the ash surface. Element solubilities of Grímsvötn ash 
regarding bulk ash composition were $<1 \%$. Combining the element solubilities and the total estimated mass of tephra $\left(7.29 \times 10^{14} \mathrm{~g}\right)$, the total input of environmentally important elements were estimated to be $8.91 \times 10^{9} \mathrm{~g} \mathrm{Ca}$, $7.02 \times 10^{9} \mathrm{~g} \mathrm{~S}, 1.10 \times 10^{9} \mathrm{~g} \mathrm{Cl}, 9.91 \times 10^{8} \mathrm{~g} \mathrm{Mg}, 9.91 \times 10^{8} \mathrm{~g} \mathrm{Fe}$ and $1.45 \times 10^{8} \mathrm{~g} \mathrm{P}$ The potential environmental problems were mainly associated with the release of $F\left(5.19 \times 10^{9} \mathrm{~g}\right)$.

Keywords: volcanic ash, water leaching, geochemical flux, Grímsvötn 


\section{Introduction}

2 Explosive volcanic eruptions produce mixtures of particulate matter (tephra) and

3 gases that are directly injected into the atmosphere. The interaction of tephra

4 particles with the environment may induce a range of positive and negative

5 physical, chemical and biological effects from local to global scales (Ayris and

6 Delmelle 2012). It is well known that eruptive columns reaching tropospheric

7 and stratospheric heights can have detrimental consequences for the climate,

8 including an increase in greenhouse gases, sulphur and halogen species, as

9 well as aerosols, which could lead to the acidification of precipitation (Robock

10 2000; Fontijn et al. 2014; Long et al. 2014). On the other hand, volatiles

11 released during an explosive volcanic eruption are usually adsorbed onto the

12 surface of volcanic ash particles as water-soluble compounds (Rose 1977; Ayris

13 and Delmelle 2012). Scavenging of volatiles is variable, with the main elements

14 being sulphur, chlorine and fluorine (Delmelle et al. 2007). After deposition, the

15 adsorbed compounds can be released to the environment where they have the

16 potential to damage water quality, vegetation, livestock and people, although in

17 some cases these effects may be positive, e.g., fertilizing lands and oceans

18 (Wearie and Manly 1996; Duggen et al. 2010; Frogner et al. 2001; Langmann et

19 al. 2010; Witham et al. 2005). An important factor of such compounds is that

20 they dissolve rapidly in contact with water (Olgun et al. 2011; Ayris and Delmelle

21 2012; Ruggieri et al. 2012a, b).

22 Other potential human impacts generated by the emission of tephra into the

23 atmosphere include respiratory health hazards for the local population (Horwell

24 and Baxter 2006; Horwell et al. 2013), as well as severe problems for aviation

25 (Casadevall 1994; Guffanti et al. 2009). Recent examples of environmental and 
26 social impacts of volcanic particulate matter are found in the 2010

27 Eyjafjallajökull and 2011 Grímsvötn (Iceland) eruptions. Both generated a low

28 impact globally, although they caused great disruption to air traffic across

29 Europe, especially the 2010 Eyjafjallajökull eruption (Webster et al. 2012;

30 Witham et al. 2012), and direct effects in Iceland as a result of the ash fall, such

31 as physical damage to roads and bridges, impact on health and loss of crops

32 (Horwell et al. 2013).

33 The aim of this work is to assess the main geochemical features of the

34 environmental impact of volcanic ash-water interaction using the results of

35 different leaching methods as proxies, through an analysis of the May 2011

36 Grímsvötn eruption. This work complements the findings of previous studies on

37 this recent volcanic eruption (Oskarsson and Sverrisdóttir 2011; Horwell et al.

38 2013; Olsson et al. 2013; Sigmarsson et al. 2013), through the analysis of a

39 distinct set of samples and the use of distinct leaching methodologies from

40 previous works on the same eruption, allowing to determine more accurately the

41 potential geochemical fluxes associated with the interaction of volcanic ash with

42 water.

\section{Geological setting}

44 The active Grímsvötn volcanic system (GVS) is aligned along a NE-SW fissure 45 system in south-central Iceland which lies partly beneath the vast Vatnajökull

46 icecap (Fig. 1). Grímsvötn central volcano is located above the Iceland mantle

47 plume, and thus has the highest rate of magma supply along the GVS. Laki

48 fissure is located within the ice-free section of the GVS; in 1783-1784 it

49 produced the largest historic lava flow on Earth, erupting about $14.7 \mathrm{~km}^{3}$ of lava 
50 and ejecting $0.4 \mathrm{~km}^{3}$ of dense-rock equivalent volume ( $\left.\mathrm{V}_{\mathrm{DRE}}\right)$ of tephra

51 (Thordarson and Self 2003). The most recent events in the GVS are the 1996

52 Gjálp subglacial fissure eruption (Gudmundsson et al. 1997), and the smaller

53 eruptions of 1998 (Sturkell et al. 2003) and 2004 (Jude-Eton et al. 2012). During

54 an eruption, the extensive geothermal activity beneath the Vatnajökull icecap

55 and the subglacial lake bound to the main caldera (Agustsdottir and Brantley

56 1994; Alfaro et al. 2007) can enhance magma-water interactions

57 (phreatomagmatic eruption) generating a tephra-laden plume that can rise

58 rapidly to the upper troposphere.

59 The Grímsvötn eruption, which started approximately at 17:30 UTC on 21 May,

60 2011, was accompanied by an earthquake swarm. The highest eruptive

61 intensity was recorded a few hours after the onset of the eruption when the

62 plume reached a maximum altitude of $20-25 \mathrm{~km}$ (Petersen et al. 2012;

63 Hreinsdottir et al. 2014). After 24 hours the ash plume had reached about 100

$64 \mathrm{~km}$ to the SW, affecting the villages of Kirkjubærklaustur and Vík (Fig. 1).

65 Visibility in this area during the first few hours was extremely poor. In the

66 following days, winds spread the ash plume over Iceland and distal fallout was

67 even observed in the British Isles, Scandinavia (Kerminen et al. 2011; Tesche et

68 al. 2012), and Baltic countries (Kvietkus et al. 2013). After the first 24 hours of

69 the eruption, the volcanic plume decreased gradually, reaching heights closer to

$7010 \mathrm{~km}$. On 23 May the height of the plume decreased to $5 \mathrm{~km}$, and on 28 May

71 the volcanic tremors rapidly decreased and finally disappeared at 07:00 UTC

72 (Hreinsdottir et al. 2014). The 21-28 May 2011 eruption was Grímsvötn's largest

73 since 1873, with a Volcanic Explosivity Index (VEI) of magnitude 4 (Hreinsdottir

74 et al. 2014), thus representing a high potential risk through releasing various 
75 elements into water, specially fluorine, which can cause diseases in both

76 animals and humans. Although this volcanic event caused some disruption to

77 European airspace, it was minor compared to the 2010 Eyjafjallajökull eruption.

\section{Methods}

79 Fieldwork was conducted across affected regions of southwestern Iceland on

8022 and 25 May, 2011. Most of the ash was released from Grímsvötn before 23

81 May (Petersen et al. 2012; Olsson et al. 2013), thus sample ISG-0 (Table 1),

82 collected on 22 May at 14:02 UTC, might not contain volcanic ash from the

83 paroxysmal phases of the eruption. The rest of the samples (eight) were

84 collected on 25 May, from $14: 32$ to $18: 27$ UTC. It should be noted that

85 sometimes it was slightly rainy during sampling on 25 May. Accordingly, the

86 sampled ash from this day probably underwent some interaction with water, and

87 therefore we classify these samples as fresh rather than pristine. Sampling was

88 carried out along a $100 \mathrm{~km}$ transect across the dispersal axis, following the

89 main road through southern Iceland (Fig. 1). This work thus focuses on the

90 effects of the eruption over the downwind region. The ash samples were

91 collected at five sites located at different distances from the vent using a

92 stainless steel shovel (Table 1 and Figs. 1 and 2). Once collected, they were

93 placed in polyethylene bags and transported to the laboratory in which they

94 were dried at $40{ }^{\circ} \mathrm{C}$ for 24 hours in an oven and stored in polyethylene vessels

95 until analysis.

96 Particle size distribution was obtained by laser diffractometry. Morphology and

97 chemistry of ash particles were studied by scanning electron microscope

98 (SEM). Mineralogy was determined by X-ray diffraction (XRD). Concentrations 
99 of major and trace elements in bulk ash samples and leachates were

100 determined by high resolution-inductively coupled plasma-mass spectrometry

101 (HR-ICP-MS). Additional information on analytical methods is provided in the

102 supplementary material.

103 The volcanic ash leaching experiments were carried out using two independent

104 methods, including a series of batch leaching tests and a flow-through column

105 leaching test. In the batch experiments, $1 \mathrm{~g}$ of each ash sample was mixed with

$10610 \mathrm{ml}$ of Milli-Q Plus ultrapure water type $(18.2 \mathrm{M} \Omega / \mathrm{cm})$ in $14 \times 100 \mathrm{~mm}$

107 polypropylene test tubes (Ruggieri et al. 2012a and 2012b). Deionised water

108 was chosen as the leachant because it allows a rapid screening of the

109 potentially hazardous species leached from the ash (Witham et al. 2005) and

110 the results are more reliable simulating the leaching by rainwater and are

111 independent of the local surface and groundwater chemistry. The water

112 leachates were shaken at $20 \mathrm{rpm}$ for $4 \mathrm{~h}$ and subsequently filtered through

113 polyvinylidene difluoride (PVDF) syringe filters with tube tips (Whatmann, 25

$114 \mathrm{~mm}$ diameter and $0.45 \mu \mathrm{m}$ pore size). Finally, $1 \%$ (v/v) $\mathrm{HNO}_{3}$ was added to

115 bring the volume up to $100 \mathrm{ml}$. The $\mathrm{pH}$ and the specific conductivity (SC) of

116 batch leachates were monitored by means of specific electrodes (Crison

117 Multimeter MM40) immediately after mixing the ash and the deionised water

$118\left(\mathrm{pH}_{0}\right.$ and $\left.\mathrm{SC}_{0}\right)$, and after shaking $\left(\mathrm{pH}_{\mathrm{f}}\right.$ and $\left.\mathrm{SC}_{\mathrm{f}}\right)$, prior to filtering. The methods

119 used to determine major and trace elements by HR-ICP-MS analysis were

120 based on a previous study (Fernandez-Turiel et al. 2000). Sulphur

121 concentrations are expressed as $\mathrm{SO}_{4}{ }^{-2}$ in the leachates. Fluoride concentrations

122 were determined in the batch leachates prior to filtering using an ion selective

123 electrode (ISE) for fluoride (Orion, Thermo Scientific). 
124 For the flow-through column leaching test, an $8 \mathrm{~cm}$-long and $2.25 \mathrm{~cm}^{2}$ cross125 sectional-area vertical column (Teledyne ISCO Ref. 69-3873-140) was filled with $12610 \mathrm{~g}$ of the representative ISG-3 ash, as in previous studies (Ruggieri et al. 127 2012a). Column loading was carried out gradually, allowing the water to 128 percolate through the ash but avoiding the development of air bubbles. A silica 129 filter with an average pore size diameter of $60 \AA$ was attached at the column 130 inlet and outlet. A peristaltic pump (Miniplus 3, Gilson) at the head of the column 131 ensured a constant and stable deionised flow of water (Milli-Q Plus type, 18.2 $132 \mathrm{M} \Omega / \mathrm{cm}$ ) from top to bottom at an average discharge of $0.12 \mathrm{ml} / \mathrm{min}$ with ash133 water contact time of around 150 minutes. A fraction collector (FC 204, Gilson) 134 at the column outlet directed samples from the leaching solution into $14 \times 100$ $135 \mathrm{~mm}$ polypropylene test tubes. We employed the drop mode collection, counting 136400 drops per tube of aqueous solution from the column outlet. One litre of 137 percolated solution was collected in 6 days, resulting in a set of 100 tube 138 samples. A subset of 37 samples was analysed for major and trace elements by 139 HR-ICP-MS, based on a previous study (Fernandez-Turiel et al. 2000) using 140 acidified $\left(1 \% \mathrm{HNO}_{3}\right)$ dilutions of $1: 10 \mathrm{ml}$, v/v, with Milli-Q Plus type deionised 141 water. Another subset of 39 samples was analysed for $\mathrm{pH}$ and SC (Crison 142 Multimeter MM40) immediately after tube filling. Samples were stored at $4{ }^{\circ} \mathrm{C}$ 143 until analysis.

\section{Results and discussion}

145 A total of nine samples were collected along the main plume dispersion axis. 146 The ash fall deposited a practically continuous grey to dark grey blanket up to $147 \sim 100 \mathrm{~km}$ to the SW of the Grímsvötn vent in Iceland. A maximum thickness of $14830 \mathrm{~cm}$ was observed $75 \mathrm{~km}$ from the vent in the Skaftá riverbank near 
149 Kirkjubæjarklaustur (sampling site ISG-3, Fig. 2). The closest ash fall deposits

150 to the eruptive focus showed two beds separated by a planar boundary. The

151 lower bed had planar lamination (Fig. 2a). Sample ISG-7 was collected from

152 the thicker ash layer $(10 \mathrm{~cm})$ in the lower section of the tephra deposit, whereas

153 ISG-8 was collected from the thinner ash layer $(0.5 \mathrm{~cm})$ in the upper section

154 (Fig. 2a). Samples ISG-5 (top) and ISG-6 (bottom) were collected a few meters

155 from the previous outcrop where this two-layer structure was less clear. The rest

156 of the samples were collected from deposits with no evidence of bedding or

157 lamination (Figs. 2b-2d).

158 The composition of the 2011 Grímsvötn ash ranged from basaltic to basaltic 159 andesite, with silica content ranging from 50.94 to $56.14 \%, \mathrm{~m} / \mathrm{m}$ (Table 1). The 160 samples are fairly homogeneous in terms of major oxide composition (Table 1), 161 with a broader compositional range for the trace elements. The highest variation 162 coefficients (20-50 \%) were shown by V, Cr, As and W.

163 The particle size distribution of the volcanic ash deposits allows two main 164 groups of samples to be distinguished (Fig. 3). The first group consists of 165 unimodal and bimodal size distribution samples, although the dominant modes 166 of the latter group are similar to those of the unimodal size distribution. The size 167 distributions of ash with a maximum of between 72 and $125 \mu \mathrm{m}$ show that the 168 finer modes are in the more distal outcrops. The second group contains a 169 bimodal distribution, with the dominant mode $(753 \mu \mathrm{m})$ being coarser than that 170 observed in the previous group (ISG-8) (Fig. 3b). The difference in particle size 171 distribution might be related to variations in fragmentation associated with 172 fluctuations in the volume of water interacting with magma; the ash is finer when 173 the water content increases (Liu et al. 2015). Thus, water might have played a 
174 lesser role during the last eruptive period, causing the magma to fragment into 175 coarser ash (sample ISG-8). The origin of the polymodal distribution of ISG-5 is 176 not clear, but could be related to plume transport or wind reworking. Another 177 application for particle size analysis of volcanic ash is the assessment of 178 potential breathing hazards. 'Thoracic' or $\mathrm{PM}_{10}(<10 \mu \mathrm{m})$ particles are likely to 179 cause respiratory diseases and 'respirable' or $\mathrm{PM}_{4}(<4 \mu \mathrm{m})$ particles can have 180 the greatest toxic potential (Horwell and Baxter 2006). The particle size analysis 181 of the Grímsvötn ash showed $\leq 2.7$ vol $\%$ for $<4 \mu \mathrm{m}$ and $\leq 6.0$ vol $\%$ for $10 \mu \mathrm{m}$, 182 which is consistent with the previous studies performed with different ash 183 samples from the same eruption ( $<3.5 \mathrm{vol} \%<4 \mu \mathrm{m}$ and $<8.4 \mathrm{vol} \%<10 \mu \mathrm{m}$ ) 184 (Horwell et al. 2013). In comparison, in the 2010 Eyjafjallajökull eruption has 185 been found higher percentages of 'thoracic' and 'respirable' particles (2-13 vol $186 \%$ for $<4 \mu \mathrm{m}$ and $4-26$ vol $\%$ for $<10 \mu \mathrm{m})$, varying with the eruptive phase 187 (Horwell et al. 2013). Taking into account the population density of southern 188 Iceland (<3 inhabitants $/ \mathrm{km}^{2}$ ) (EEA 2010) and the exposure time ( 8 days), the 189 respiratory health risk of the Grímsvötn ash was low during the eruption and 190 lower still than for the 2010 Eyjafjallajökull eruption.

191 Based on SEM and XRD analyses, the 2011 Grímsvötn ash has >90 \% juvenile 192 glass particles. The glass is associated with plagioclase, clinopyroxene, 193 diopside and olivine phenocrysts. This mineralogical composition is coherent 194 with data from previous studies on the erupted 2011 Grímsvötn ash (Olsson et 195 al. 2013; Sigmarsson et al. 2013). An iron sulfide was also present as a minor 196 phase (stoichiometric calculations were made assuming pyrite as the mineral 197 phase observed), which was detected in the XRD measurements for the sample 198 ISG-4. Although some rare occurrences of sulphide globules were indicated 
199 previously in Grímsvötn 2011 ash (Sigmarsson et al. 2013), the presence of iron 200 sulfides, which are highly soluble in water, are presented for first time in this 201 study.

202 General and detailed SEM images show that blocky shards are very angular 203 and poorly to nonvesicular with curviplanar breakage surfaces (Figs. 4a-b). 204 More rarely, fluidal particles with elongate vesicles (Fig. 4b) and spherical 205 shapes (Fig. 4c) were found. Minor phases such as plagioclase, clinopyroxene, 206 diopside and olivine are difficult to identify using the SEM because glass usually 207 surrounds these crystals. Instead, iron sulfide formed subspherical aggregates 208 of subhedral cubic crystals, partially covered by or free of glass (Fig. 4d). The 209 origin of this iron sulfide is probably the same as that proposed for the sulphide 210 globules, i.e., generated by basalt-sulphide melt exsolution before degassing of 211 the magma (Sigmarsson et al. 2013). The rim textures vary, probably related to 212 differences in cooling rates.

213 The observed ensemble of shard morphologies is due to the explosive 214 interaction of magma with water that favoured the particle fragmentation. Ash 215 particle aggregates are scarce and could be associated with processes of early 216 ash aggregation in the plume (Bonadonna et al. 2011; Taddeucci et al. 2011). 217 This feature is expressed as bimodality in the particle size distribution of some 218 samples (Fig. 3). However, due to the high water content and the height of the 219 eruption column, more aggregates were expected to be found (Brown et al. 220 2012). This scarcity of aggregates could be related to the break-up of aggregate 221 during ash fall, as in the 2010 Eyjafjallajökull eruption (Taddeucci et al. 2011). 
222 We tried to obtain some proxies for the chemical processes occurring during the

223 interaction of ash and water by means of the batch leaching experiments. This

224 is a simple and fast way to establish the leaching rates of the elements during

225 this interaction. A key question at this point is the 'pristineness' of the volcanic

226 ash. Ash samples collected after or during rainfall are different to ash collected

227 under dry conditions due to mobilization of different salts from ash at different

228 rates during the initial ash-water interaction (Taylor and Lichte 1980; Jones and

229 Gislason 2008; Ruggieri et al. 2012a). Accordingly, leachate data might be

230 compromised by rainfall in samples ISG-1 to ISG-8, leading to our classification

231 of them as fresh rather than pristine. In consequence, the results presented in

232 this work must not be taken as 'absolute' fluxes of the eruption; however, they

233 fingerprint the 2011 Grímsvötn eruption and indicate the order of magnitude of

234 the fluxes involved.

235 Results of the single batch leaching tests showed a water-leach solution which 236 was slightly acidic immediately after the ash-water interaction, with the

237 exception of three samples which were weakly alkaline, ranging from $\mathrm{pH} 5.80$ to

2387.62 (Table 2). After shaking for 4 hours, the average $\mathrm{pH}$ of leachates increased

239 by around $1.90 \mathrm{pH}$ units, resulting in solutions whose $\mathrm{pH}$ ranged between 7.33

240 and 9.26. This increase can be explained by ionic exchange, i.e., dissolution of

241 surface cations and protons of glass and minerals (Gislason and Oelkers 2003;

242 Ruggieri et al. 2010). The behaviour of the explosive ash from Eyjafjallajökull in

2432010 was similar, with a slightly more basic $\mathrm{pH}(\mathrm{pH} 8)$ which rose after the ash-

244 water mixing (Gislason et al. 2011). The initial values of specific conductivity

245 (SC) ranged from 7-356 $\mu$ S/cm (Gislason et al. 2011), increasing in all samples

246 in the final solutions to a range of $14-404 \mu S / \mathrm{cm}$ (Table 2). The samples with 
247 lower values of $\mathrm{pH}$ and SC were ISG-5 and ISG-8, the coarser samples and 248 probably more affected by rain (Table 2 and Fig. 3).

249 When the batch results of this work are compared with data from other tephra250 leachate studies (Ayris and Delmelle 2012), the Grímsvötn leaching results are 251 at the lower end of the ranges, with clearly lower means and medians, even 252 taking into account the rain effect and the differences in leaching 253 methodologies. The Grímsvötn leaching results are in agreement with the 254 observations in previous works (Ruggieri et al. 2012b; Witham et al. 2012; 255 Olsson et al. 2013).

256 Table 3 compares the batch leached fraction of a Grímsvötn ash (sample ISG-3) 257 with Chaitén 2008 eruption (Chile) and Eyjafjallajökull 2010 eruption (Iceland). 258 The 2008 Chaitén eruption (Ruggieri et al. 2012a) was rhyolitic in composition 259 and is located in a different geological setting, but the batch test was carried out 260 following the same methodology as the one used for the 2011 Grímsvötn ash. In 261 contrast, the 2010 Eyjafjallajökull eruption was compositionally closer to 262 Grímsvötn, and both were located in the same geotectonic setting. However, 263 these samples of the Phase I eruption were not pristine and the solute/ash ratio 264 (1:25), agitation type and time $(2 \mathrm{~h})$ used in the batch test were different 265 (Bagnato et al. 2013).

266 Despite the differences, their leached fractions produce similar results in terms 267 of order of magnitude for major elements. The exceptions are $\mathrm{Cl}$ and $\mathrm{K}$, which 268 are exceptionally low in the Grímsvötn ash. The remarkably low release of $\mathrm{Cl}$ 269 was also found in column leachates (Olsson et al. 2013). Overall, minor and 
270 trace elements are leached at lower rates in the Grímsvötn than in the Chaitén

271 and Eyjafjallajökull ashes.

272 A proxy for the mobility of elements during the ash-water interaction is the 273 relative mass leached (RML) which is defined as the percentage of the element 274 that can be mobilised through ash-water interaction, and it is expressed as the 275 fraction of the leached element obtained from the batch experiment (Conc $\mathrm{batch}_{\text {) }}$ 276 over the element's bulk concentration (Conc bulk $_{\text {b }}$. Therefore, RML is expressed 277 as RML \% = Conc $_{\text {batch }} /$ Conc $_{\text {bulk }}$ * 100 (Table 3).

278 To determine the leached mass for each element, we need to know the total 279 mass of tephra erupted in 2011 by Grímsvötn volcano, which can be estimated 280 using the dense-rock equivalent volume $\left(\mathrm{V}_{\mathrm{DRE}}\right)$ and the density $\left(\rho_{\mathrm{DRE}}\right)$. The $\mathrm{V}_{\mathrm{DRE}}$ 281 expresses the volume without the void spaces in the ash particles (vesicles) 282 and the inter-particle space. The $V_{D R E}$ was estimated as being $0.27 \pm 0.07 \mathrm{~km}^{3}$ 283 for this eruption (Hreinsdottir et al. 2014). Assuming a $\rho_{\text {DRE }}$ of $2700 \mathrm{~kg} / \mathrm{m}^{3}$, the 284 resulting mass is $7.29 \times 10^{14} \mathrm{~g}$. The results obtained for the studied elements are 285 in Table 3.

286 Each element was classified arbitrarily according to their RML mobility proxy, 287 differentiating between elements with moderate (RML 0.5 to $1.00 \%$; Sn), low 288 (0.01 to $0.5 \%$; As, Bi, W, Pb, Sb, TI, Li, Mo, Zn, Na, Cu, K, Cs, Ca, Sr, Ni, P, Be, $289 \mathrm{Rb}, \mathrm{Tb}$ and $\mathrm{Ta})$ and very low mobility (RML $<0.01 \%$; Ge, Rare Earth Elements 290 or REE, Th, Y, Ba, Mg, Mn, Ga, Al, Hf, V, Cr, Co, Fe, Nb, Sc, U, Zr, Ti, Si and $291 \mathrm{Ag}$ ). The results show a small degree of mobility for all elements, and 292 remarkably low for major elements. Although the concentrations of $\mathrm{Cl}, \mathrm{S}, \mathrm{B}, \mathrm{F}$, $293 \mathrm{Se}, \mathrm{Br}, \mathrm{Cd}, \mathrm{I}$ and $\mathrm{Hg}$ were analysed in the batch experiments, their RML could 
294 not be estimated since their bulk compositions were not determined. Despite

295 the low mobility of elements, the overall quantity released into water may be 296 sizeable (Table 3) by combining the element solubilities and the total estimated 297 mass of tephra. Grímsvötn ash contains notable contents of potential 298 macronutrients $\left(8.91 \times 10^{9} \mathrm{~g} \mathrm{Ca}, 7.02 \times 10^{9} \mathrm{~g} \mathrm{~S}, 9.91 \times 10^{8} \mathrm{~g} \mathrm{Mg}\right.$ and $\left.1.45 \times 10^{8} \mathrm{~g} \mathrm{P}\right)$ 299 and micronutrients $\left(1.10 \times 10^{9} \mathrm{~g} \mathrm{Cl}\right.$ and $\left.9.91 \times 10^{8} \mathrm{~g} \mathrm{Fe}\right)$ for biological processes, 300 which show the fertilising potential of the ash both in terrestrial ecosystems 301 (Wearie and Manly 1996) and in the surface water of oceans (Duggen et al. 302 2010; Olgun et al. 2013). Although these values give an estimation of the 303 impacts on marine environment, a leachate study using natural seawater would 304 determine more precisely the impact of the Grímsvötn ash in oceanic waters. 305 Potential environmental problems arising from ash fallout on land or into fresh 306 water systems, on the other hand, are mainly associated with the release of 307 fluoride $\left(5.19 \times 10^{9} \mathrm{~g} \mathrm{~F}\right)$, with the hazard of other potentially toxic elements or 308 compounds being extremely low in comparison. It can be observed when 309 contrasting the potential leachable mass of the 2010 Eyjafjallajökull (Bagnato et 310 al. 2013; Gudmundsson et al. 2012) with the 2011 Grímsvötn eruption, that the 311 potential release of macronutrients $\left(4.79 \times 10^{10} \mathrm{~g} \mathrm{Ca}, 1.48 \times 10^{10} \mathrm{~g} \mathrm{~S}, 2.63 \times 10^{9} \mathrm{~g}\right.$ $312 \mathrm{Mg})$ and $\mathrm{Cl}\left(5.57 \times 10^{10} \mathrm{~g}\right)$ to the environment for the former ash was higher, 313 except for Fe $\left(3.65 \times 10^{8}\right)$. The potential leachable mass of fluoride in the 2010 314 eruption was also higher $\left(1.53 \times 10^{10} \mathrm{~g}\right)$ in the Eyjafjallajökull ash. The sulphur 315 fluxes of the 2011 Grímsvötn eruption have been studied previously 316 (Sigmarsson et al. 2013). These authors estimate that $7.3 \times 10^{11} \mathrm{~g}$ of $\mathrm{S}$ were 317 emitted during this eruption, which can be broken down to $7.2 \times 10^{11} \mathrm{~g}$ of $\mathrm{S}$ as $318 \mathrm{SO}_{2}$ gas detected by satellite $(26 \%), 1.2 \times 10^{11} \mathrm{~g}$ of leachable $\mathrm{S}(16 \%)$, 
$3193.7 \times 10^{10} \mathrm{~g}$ of $\mathrm{S}$ released in the jöhulhlaups $(5 \%)$, and $3.8 \times 10^{11} \mathrm{~g}$ of $\mathrm{S}$ in 320 sulphide globules (53\%). The value obtained for the leachable S content was 321 taken from previous estimations (Olsson et al. 2013). The leachable S value is 322 notably lower in the present work, independent of the leaching method, 323 probably due to prior leaching during rainfall. The results from both previous 324 work and this study on sulphide estimates are equivalent to $\sim 0.3 \%$ of pyrite, 325 which is coherent with our observations by XRD and SEM.

326 The flow-through column leaching test allows the evolution of the leached 327 composition over time to be modelled. The test was carried out with sample 328 ISG-3 due to its representativeness within the 2011 Grímsvötn eruption ash 329 collection. Its selection was done following field and laboratory criteria. Firstly, it 330 was one of the samples not visually affected by rain during sampling, and 331 secondly it is the sample with the most representative particle size distribution. 332 The results are given in Table S1 (supplementary material) and Fig. 5, where 333 they are plotted as progression curves of $\mathrm{pH}$, major and trace elements versus 334 accumulated volume of the percolated solution (Fig. 5).

335 The $\mathrm{pH}$ ranges from 6.55 to 7.10 , increasing rapidly at the very beginning of the 336 experiment. This trend has been commonly reported in other volcanic ash 337 column leaching tests (Rango et al. 2010; Ruggieri et al. 2010). Once pH has 338 reached its maximum (7.10), the general trend is towards a progressive 339 decrease for about 0.3 units from the beginning to the end, following a saw340 tooth pattern. The initial rise in $\mathrm{pH}$ was also recognized in the batch experiment 341 and it is likely due to the virtually instantaneous exchange of the alkaline ion by $342 \mathrm{H}^{+}$(or as $\left(\mathrm{H}_{3} \mathrm{O}^{+}\right)$, i.e., increase in $\mathrm{pH}$ (Ruggieri et al. 2010). The concentrations 343 of the elements in the percolated solution tend to decrease gradually through 
344 time. The high incipient concentrations of $\mathrm{SO}_{4}{ }^{2-}, \mathrm{Na}, \mathrm{Ca}, \mathrm{Mg}, \mathrm{K}$ and $\mathrm{Sr}$ (Fig. 5)

345 confirm the presence of soluble compounds on ash particle surfaces, originating

346 from interaction between tephra and volcanic gases within the eruption column

347 (Rose 1977; Delmelle et al. 2007). A considerable number of elements show a 348 major peak in concentration between 50 and $60 \mathrm{ml}$ of percolated solution, which

349 sometimes exceeds the initial concentrations ( $\mathrm{Si}, \mathrm{Al}, \mathrm{P}, \mathrm{Ti}, \mathrm{V}, \mathrm{Fe}, \mathrm{Ni}, \mathrm{Cu}, \mathrm{Zn}, \mathrm{Zr}$ 350 and $\mathrm{Ba}$ ). This anomaly in the decreasing trend may be due to the incongruent 351 dissolution of volcanic glass by cation-exchange processes (Rango et al. 2010;

352 Ruggieri et al. 2010). Towards the end, the element concentrations become 353 stable, suggesting that the most leachable fraction is exhausted. This situation 354 is reached at relatively small percolated volumes for $\mathrm{Na}$, Si and $\mathrm{Cl}(\sim 150 \mathrm{ml})$, 355 indicating a very fast release of these elements, while the stabilization of 356 element concentration for $\mathrm{Ti}, \mathrm{Mn}$ and $\mathrm{Zn}$ is notably higher, by up to 4 times $357(\sim 600 \mathrm{ml})$, indicating a more prolonged release over time.

358 When the discrete column leaching results are plotted on the Chadha diagram 359 (Chadha 1999) for identification of hydrochemical processes, the values group 360 into three sets based on the evolution of the leachate composition (Fig. 6). Set 1 361 is made up of a single solution that corresponds to the onset of the experiment. 362 Set 2 shows a significant decrease in anion content $\left(\mathrm{Cl}^{-}\right.$and $\left.\mathrm{SO}_{4}{ }^{2-}\right)$ in the 363 solution, whereas set 3 is characterized by a notable reduction in $\mathrm{Na}, \mathrm{K}, \mathrm{Ca}$ and $364 \mathrm{Mg}$ contents, reaching a generally stable situation where no more significant 365 changes are observed (Fig. 6). The batch results are close to the starting value 366 of the column experiment in Fig. 6, with the exception of samples ISG-5 and 367 ISG-8, which also show anomalous behaviour here. This behaviour is 368 interpreted as being partially related to their exposure to rain, and thus the plot 
369 of leaching results on a Chadha diagram could be a useful tool for

370 distinguishing non pristine ash samples. In addition, these two samples belong

371 to the coarser group of samples, pointing out that the anomalous behaviour

372 observed in the Chadha plot could be also related with the fact that finer ash

373 present a larger surface/volume ratio promoting the conditions for the formation

374 of soluble salts on ash surface.

375 The element masses released in the column experiment are lower than in the

376 batch tests (Table 3 ). These masses were estimated by interpolating values

377 between analysed samples to complete the data for the total percolated volume.

378 Variations between elements are due to the different physicochemical

379 conditions during the experiments. For the major elements, Si has the closest

380 values for the two methods $\left(8.60 \times 10^{8} \mathrm{~g}\right.$ in batch vs. $8.17 \times 10^{8} \mathrm{~g}$ in column). On

381 the other hand, $\mathrm{S}$ and $\mathrm{Cl}$ have the largest differences $\left(7.02 \times 10^{9}\right.$ vs. $9.73 \times 10^{8} \mathrm{~g}$

382 for $\mathrm{S}$ and $1.09 \times 10^{9}$ vs. $1.40 \times 10^{8} \mathrm{~g}$ for $\mathrm{Cl}$, for batch and column tests, 383 respectively). Assuming that batch results reflect the maximum available 384 elemental content of an ash, the column results corroborate their fast release 385 into the environment for practically all the studied elements when ash interacts 386 with water.

\section{Conclusions}

388 The study of the ash generated during the May 2011 eruption of the Icelandic 389 volcano Grímsvötn demonstrates the complementary nature of batch and 390 column leaching experiments in the assessment of the environmental 391 consequences of ejection of ash into the atmosphere and its later deposition on 392 terrestrial and aqueous surfaces. Furthermore, it helps consolidate the 
393 methodology for the environmental study of volcanic ash, while at the same

394 time providing new tools to distinguish pristine from non pristine samples.

395 In this scenario, the main findings regarding the May 2011 eruption of 396 Grímsvötn volcano reveal that $\mathrm{Na}, \mathrm{K}, \mathrm{Ca}, \mathrm{Mg}, \mathrm{Si}, \mathrm{Cl}, \mathrm{S}$ and $\mathrm{F}$ show the largest 397 geochemical fluxes caused by the interaction of water and ash. Additionally, the 398 significant amounts of some of these elements ( $\mathrm{Ca}, \mathrm{S}$ and $\mathrm{Mg}$ ) together with $\mathrm{P}$, $399 \mathrm{Cl}, \mathrm{Fe}$, which are usually considered as macro/micronutrients, demonstrates the 400 fertilising potential of the May 2011 emitted ash. On the other hand, release of $F$ 401 highlights the possible environmental problems arising from ash fallout on land 402 or into fresh water systems. It is noteworthy that the chemical release is 403 maximal during the first few hours of contact between tephra and water due to 404 the dissolution of soluble salts from the ash surface. As time progresses, these 405 constituents are exhausted, the release drops considerably and elements are 406 freed instead by the incongruent dissolution of the volcanic glass. In addition, 407 the scarce presence of iron sulphide, which is very rare in juvenile ash, 408 underlines the singularity of this sample collection.

\section{Acknowledgments}

410 We gratefully acknowledge the assistance of ICTJA-CSIC labGEOTOP 411 (infrastructure co-funded by ERDF-EU Ref. CSIC08-4E-001) and DRX 412 (infrastructure co-funded by ERDF-EU Ref. CSIC10-4E-141) Surveys (J. 413 Ibañez, J. Elvira and S. Alvarez) and the CCiTUB (SEM Unit) in the analytical 414 work. Financial support was provided by the QUECA Project (MINECO, 415 CGL2011-23307). We appreciate the invaluable comments of Dr. N. Olgun on a 416 previous version of the manuscript. This study was carried out in the framework 
417 of the Research Consolidated Groups GEOPAM (Generalitat de Catalunya,

\section{References}

Agustsdottir AM, Brantley SL (1994) Volatile fluxes integrated over 4 decades at Grimsvotn volcano, Iceland Journal of Geophysical Research-Solid Earth 99:9505-9522 doi:10.1029/93jb03597

Alfaro R, Brandsdottir B, Rowlands DP, White RS, Gudmundsson MT (2007) Structure of the Grimsvotn central volcano under the Vatnajokull icecap, Iceland Geophysical Journal International 168:863-876 doi:10.1111/j.1365246X.2006.03238.x

Ayris PM, Delmelle P (2012) The immediate environmental effects of tephra emission Bull Volcanol 74:1905-1936 doi:10.1007/s00445-012-0654-5

Bagnato E et al. (2013) Scavenging of sulphur, halogens and trace metals by volcanic ash: The 2010 Eyjafjallajokull eruption Geochimica Et Cosmochimica Acta 103:138-160 doi:10.1016/j.gca.2012.10.048

Bonadonna C et al. (2011) Tephra sedimentation during the 2010 Eyjafjallajokull eruption (Iceland) from deposit, radar, and satellite observations Journal of Geophysical Research-Solid Earth 116 doi:10.1029/2011jb008462

Brown RJ, Bonadonna C, Durant AJ (2012) A review of volcanic ash aggregation Physics and Chemistry of the Earth 45-46:65-78 doi:10.1016/j.pce.2011.11.001

Casadevall TJ (1994) Volcanic ash and aviation safety; proceedings of the First international symposium on Volcanic ash and aviation safety. USGS Bulletin, vol 2047.

Chadha DK (1999) A proposed new diagram for geochemical classification of natural waters and interpretation of chemical data Hydrogeology Journal 7:431-439 doi:10.1007/s100400050216

Delmelle P, Lambert M, Dufrene Y, Gerin P, Oskarsson N (2007) Gas/aerosol-ash interaction in volcanic plumes: New insights from surface analyses of fine ash particles Earth and Planetary Science Letters 259:159-170 doi:10.1016/j.epsl.2007.04.052

Duggen S, Olgun N, Croot P, Hoffmann L, Dietze H, Delmelle P, Teschner C (2010) The role of airborne volcanic ash for the surface ocean biogeochemical iron-cycle: a review Biogeosciences 7:827-844 doi:10.5194/bg-7-827-2010

EEA (2010) The European environment - state and outlook 2010: synthesis. Country assessments. Iceland. Population density. European Environment Agency, Copenhagen

Fernandez-Turiel JL, Llorens JF, Lopez-Vera F, Gomez-Artola C, Morell I, Gimeno D (2000) Strategy for water analysis using ICP-MS Fresenius Journal of Analytical Chemistry 368:601-606

Fontijn K, Lachowycz SM, Rawson H, Pyle DM, Mather TA, Naranjo JA, Moreno-Roa H (2014) Late Quaternary tephrostratigraphy of southern Chile and Argentina Quaternary Science Reviews 89:70-84 doi:10.1016/j.quascirev.2014.02.007 
462

463

464

465

466

467

468

469

470

471

472

473

474

475

476

477

478

479

480

481

482

483

484

485

486

487

488

489

490

491

492

493

494

495

496

497

498

499

500

501

502

503

504

505

506

507

508

509

510

511

512

513

514

515

516

Frogner P, Gislason SR, Oskarsson N (2001) Fertilizing potential of volcanic ash in ocean surface water Geology 29:487-490

Gislason SR et al. (2011) Characterization of Eyjafjallajokull volcanic ash particles and a protocol for rapid risk assessment Proceedings of the National Academy of Sciences of the United States of America 108:7307-7312 doi:10.1073/pnas.1015053108

Gislason SR, Oelkers EH (2003) Mechanism, rates, and consequences of basaltic glass dissolution: II. An experimental study of the dissolution rates of basaltic glass as a function of $\mathrm{pH}$ and temperature Geochimica Et Cosmochimica Acta 67:3817-3832 doi:10.1016/s0016-7037(00)00176-5

Gudmundsson MT, Sigmundsson F, Bjornsson H (1997) Ice-volcano interaction of the 1996 Gjalp subglacial eruption, Vatnajokull, Iceland Nature 389:954-957 doi:10.1038/40122

Guffanti M, Mayberry GC, Casadevall TJ, Wunderman R (2009) Volcanic hazards to airports Natural Hazards 51:287-302 doi:10.1007/s11069-008-9254-2

Horwell CJ, Baxter PJ (2006) The respiratory health hazards of volcanic ash: a review for volcanic risk mitigation Bull Volcanol 69:1-24 doi:10.1007/s00445-006-0052y

Horwell CJ et al. (2013) Physicochemical and toxicological profiling of ash from the 2010 and 2011 eruptions of Eyjafjallajokull and Grimsvotn volcanoes, Iceland using a rapid respiratory hazard assessment protocol Environmental Research 127:63-73 doi:10.1016/j.envres.2013.08.011

Hreinsdottir S et al. (2014) Volcanic plume height correlated with magma-pressure change at Grimsvotn Volcano, Iceland Nature Geoscience 7:214-218 doi:10.1038/ngeo2044

Icelandic-Meteorological-Office (2010) Grímsvötn 2010. Jökulhlaup - glacier outburst flood in 2010. http://en.vedur.is/hydrology/articles/nr/2040. Accessed $04 / 07 / 2014$

Icelandic-Metereological-Office (2011) Web-pages related to the Grímsvötn eruption 2011. Vatnajökull monitoring. GPS displacement at Grímsfjall since 2006. http://hraun.vedur.is/ja/vatnajokulsvoktun/gps_faersla.html. Accessed 04/07/2014

Jones MT, Gislason SR (2008) Rapid releases of metal salts and nutrients following the deposition of volcanic ash into aqueous environments Geochimica Et Cosmochimica Acta 72:3661-3680 doi:10.1016/j.gca.2008.05.030

Jude-Eton TC, Thordarson T, Gudmundsson MT, Oddsson B (2012) Dynamics, stratigraphy and proximal dispersal of supraglacial tephra during the iceconfined 2004 eruption at Grimsvotn Volcano, Iceland Bull Volcanol 74:10571082 doi:10.1007/s00445-012-0583-3

Kerminen VM et al. (2011) Characterization of a volcanic ash episode in southern Finland caused by the Grimsvotn eruption in Iceland in May 2011 Atmospheric Chemistry and Physics 11:12227-12239 doi:10.5194/acp-11-12227-2011

Kvietkus K, Sakalys J, Didzbalis J, Garbariene I, Spirkauskaite N, Remeikis V (2013) Atmospheric aerosol episodes over Lithuania after the May 2011 volcano eruption at Grimsvotn, Iceland Atmospheric Research 122:93-101 doi:10.1016/j.atmosres.2012.10.014

Langmann B, Zaksek K, Hort M, Duggen S (2010) Volcanic ash as fertiliser for the surface ocean Atmospheric Chemistry and Physics 10:3891-3899

Liu EJ, Cashman KV, Rust AC, Gislason SR (2015) The role of bubbles in generating fine ash during hydromagmatic eruptions Geology 43(3):239-242

Long CJ, Power MJ, Minckley TA, Hass AL (2014) The impact of Mt Mazama tephra deposition on forest vegetation in the Central Cascades, Oregon, USA Holocene 24:503-511 doi:10.1177/0959683613520258

Olgun N, Duggen S, Andronico D, Kutterolf S, Croot PL, Giammanco S, Censi P, Randazzo L (2013) Possible impacts of volcanic ash emissions of Mount Etna 
on the primary productivity in the oligotrophic Mediterranean Sea: Results from nutrient-release experiments in seawater Marine Chemistry 152:32-42 doi:10.1016/j.marchem.2013.04.004

Olgun N, Duggen S, Croot PL, Delmelle P, Dietze H, Schacht U, Oskarsson N, Siebe C, Auer A, Garbe-Schönberg D (2011) Surface ocean iron fertilization: The role of airbone volcanic ash from subduction zone and hot spot volcanoes and related iron fluxes into Pacific Ocean Global Biogeochemical Cycles 25

Olsson J, Stipp SLS, Dalby KN, Gislason SR (2013) Rapid release of metal salts and nutrients from the 2011 Grimsvotn, Iceland volcanic ash Geochimica Et Cosmochimica Acta 123:134-149 doi:10.1016/j.gca.2013.09.009

Oskarsson N, Sverrisdottir G (2011) Chemical composition and texture of ash from the Grímsvötn 2011-eruption. Institute of Earth Sciences, University of Iceland, 2011, available online at: http://earthice.hi.is/page/ies GV2011 chemical

Petersen GN, Bjornsson H, Arason P, von Löwis S (2012) Two weather radar time series of the altitude of the volcanic plume during the May 2011 eruption of Grímsvötn, Iceland Earth Syst Sci Data 4:121-127 doi:10.5194/essd-4-1212012

Rango T, Colombani N, Mastrocicco M, Bianchini G, Beccaluva L (2010) Column Elution Experiments on Volcanic Ash: Geochemical Implications for the Main Ethiopian Rift Waters Water Air and Soil Pollution 208:221-233 doi:10.1007/s11270-009-0161-2

Robock A (2000) Volcanic eruptions and climate Reviews of Geophysics 38:191-219 doi:10.1029/1998rg000054

Rose WI (1977) Scavenging of volcanic aerosol by ash - atmospheric and volcanologic implications Geology 5:621-624

Ruggieri $\mathrm{F}$ et al. (2012a) Contribution of volcanic ashes to the regional geochemical balance: The 2008 eruption of Chaiten volcano, Southern Chile Science of the Total Environment 425:75-88 doi:10.1016/j.scitotenv.2012.03.011

Ruggieri $\mathrm{F}$ et al. (2012b) Multivariate factorial analysis to design a robust batch leaching test to assess the volcanic ash geochemical hazard Journal of Hazardous Materials 213:273-284 doi:10.1016/j.jhazmat.2012.01.091

Ruggieri F, Saavedra J, Fernandez-Turiel JL, Gimeno D, Garcia-Valles M (2010) Environmental geochemistry of ancient volcanic ashes Journal of Hazardous Materials 183:353-365 doi:10.1016/j.jhazmat.2010.07.032

Sigmarsson O, Haddadi B, Carn S, Moune S, Gudnason J, Yang K, Clarisse L (2013) The sulfur budget of the 2011 Grimsvotn eruption, Iceland Geophysical Research Letters 40:6095-6100 doi:10.1002/2013gl057760

Sturkell E, Einarsson L, Sigmundsson F, Hreinsdottir S, Geirsson H (2003) Deformation of Grimsvotn volcano, Iceland: 1998 eruption and subsequent inflation Geophysical Research Letters 30 doi:10.1029/2002gl016460

Taddeucci $\mathrm{J}$ et al. (2011) Aggregation-dominated ash settling from the Eyjafjallajokull volcanic cloud illuminated by field and laboratory high-speed imaging Geology 39:891-894 doi:10.1130/g32016.1

Taylor HE, Lichte FE (1980) Chemical composition of Mount St-Helens volcanic ash Geophysical Research Letters 7:949-952 doi:10.1029/GL007i011p00949

Tesche M et al. (2012) Volcanic ash over Scandinavia originating from the Grimsvotn eruptions in May 2011 Journal of Geophysical Research-Atmospheres 117 doi:10.1029/2011jd017090

Thordarson T, Self S (2003) Atmospheric and environmental effects of the 1783-1784 Laki eruption: A review and reassessment Journal of Geophysical ResearchAtmospheres 108 doi:10.1029/2001jd002042

Weaire J, Manly R (1996) Chemical quality water studies in the Central Patagonian Region of Chile following the eruption of Volcan Hudson Hydrobiologia 331:161-166 
571 Webster HN et al. (2012) Operational prediction of ash concentrations in the distal 572 volcanic cloud from the 2010 Eyjafjallajokull eruption Journal of Geophysical Research-Atmospheres 117 doi:10.1029/2011jd016790

574 Witham C, Webster H, Hort M, Jones A, Thomson D (2012) Modelling concentrations of $575 \quad$ volcanic ash encountered by aircraft in past eruptions Atmospheric Environment 48:219-229 doi:10.1016/j.atmosenv.2011.06.073

Witham CS, Oppenheimer C, Horwell CJ (2005) Volcanic ash-leachates: a review and recommendations for sampling methods Journal of Volcanology and Geothermal Research 141:299-326 doi:10.1016/j.jvolgeores.2004.11.010 
582 Table 1. Main features of the studied ash from the 2011 Grímsvötn eruption.

583 Mineral compositions: ${ }^{* *}$, prevalent; ${ }^{* *}$, common; ${ }^{*}$, frequent; $\left({ }^{*}\right)$, scarce; nd, not 584 detected. Major oxides and loss on ignition (LOI) expressed as $\%, \mathrm{~m} / \mathrm{m}$. Trace 585 elements expressed as $\mu \mathrm{g} / \mathrm{g}$.

586 Table 2. $\mathrm{pH}$ and specific conductivity (SC) of the batch leaching tests of 587 Grímsvötn samples which were monitored immediately after mixing the ash and 588 the deionised water $\left(\mathrm{pH}_{0}\right.$ and $\left.\mathrm{SC}_{0}\right)$, and after 4 hours shaking $\left(\mathrm{pH}_{\mathrm{f}}\right.$ and $\left.\mathrm{SC}_{\mathrm{f}}\right)$ 589 without filtering. $\mathrm{SC}$ is expressed as $\mu \mathrm{S} / \mathrm{cm}$.

590 Table 3. Potential geochemical fluxes associated with the 2011 Grímsvötn 591 eruption. Data for batch (1 $\mathrm{g}$ volcanic ash was shaken with $10 \mathrm{ml}$ of deionized 592 water for $4 \mathrm{~h}$ ) and column leaching (10 $\mathrm{g}$ ash were leached in a flow-through 593 column with $1000 \mathrm{ml}$ of deionized water pumped at $0.12 \mathrm{ml} / \mathrm{min}$ ) experiments 594 are shown for the same sample (ISG-3), chosen for its preservation and particle 595 size distribution. Batch results are compared with an average of ash batch tests 596 (Ayris and Delmelle 2012), sample $\mathrm{CH}-1 \mathrm{~F}$ of 2008 Chaitén eruption (Ruggieri et 597 al. 2012a), and mean values of samples from the first eruptive phase of the 5982010 Eyjafjallajökull eruption (Bagnato et al. 2013). nd, not determined; <LoD, 599 lower than limit of detection. 


\section{Figure captions}

603 Fig. 1. Map showing the locations of volcanic ash samples, Grímsvötn volcano 604 and other active volcanoes in southern Iceland, icecaps and urban areas.

605 Fig. 2. Photographs showing the ash sampling sites located at different 606 distances from Grímsvötn volcano including; a, The most proximal to vent ash 607 fall deposit sampled $(49 \mathrm{~km})$, with two beds; the lower shows parallel 608 lamination. b, Massive deposit at site ISG-3, with the maximum thickness 609 observed $(30 \mathrm{~cm})$, at $75 \mathrm{~km}$ from the vent in the Skaftá riverbank near

610 Kirkjubæjarklaustur; the upper part was slightly hardened. c, Massive deposit on 611 the Brunná riverbank ( $57 \mathrm{~km}$ from the vent). d, Laki lava lightly covered by ash 612 (95 km from the vent).

613 Fig. 3. Particle size distribution of Grímsvötn 2011 ash of (a) samples with 614 unimodal distribution, and (b) samples with bimodal and polymodal distribution.

615 Fig. 4. SEM images of the studied ash from the 2011 Grímsvötn eruption. 616 Blocky shards are very angular and poorly to nonvesicular with curviplanar 617 breakage surfaces $(a, b)$. More scarcely, we found fluidal particles with elongate 618 vesicles (b) and spherical shapes (c). d An iron sulphide. Images a-c were 619 captured with an EverhartThornley detector (ETD), whereas $d$ was taken with a 620 backscattered electron detector (BSED). a, c ISG3. b ISG6. d ISG4

621 Fig. 5. Changes in the element concentrations, $\mathrm{pH}$ and SC of the ash-leachate 622 of ISG-3 ash sample from Grímsvötn 2011 eruption during the flow-through

623 column experiment in deionized water. Ten grams of ash were leached in a 624 flow-through column with $1000 \mathrm{ml}$ (percolate volume) of deionized water 625 pumped at $0.12 \mathrm{ml} / \mathrm{min}$ with ash-water contact time of around 150 minutes. 
626 Fig. 6. Chadha diagram (Chadha 1999) of the chemical compositions of the 627 batch ( $1 \mathrm{~g}$ of volcanic ash was shaken with $10 \mathrm{ml}$ of deionized water for $4 \mathrm{~h}$ ) 628 and column leachates (10 $\mathrm{g}$ of ash were leached in a flow-through column with $6291000 \mathrm{ml}$ of deionized water pumped at $0.12 \mathrm{ml} / \mathrm{min}$ ). This plot shows the 630 difference between divalent alkaline cations $\left(\mathrm{Ca}^{2+}\right.$ and $\left.\mathrm{Mg}^{2+}\right)$ and monovalent 631 alkaline cations $\left(\mathrm{Na}^{+}\right.$and $\left.\mathrm{K}^{+}\right)$in milliequivalent (meq) percentage over the 632 difference between weak $\left(\mathrm{HCO}^{3-}\right)$ and strong $\left(\mathrm{Cl}^{-}\right.$and $\left.\mathrm{SO}_{4}{ }^{2-}\right)$ acid anions. Red 633 numbers correspond to the different steps of the leaching process observed in 634 the column test in sample ISG-3. 


\section{Supplementary material}

636 Supplementary material - Details on analytical methods and leaching tests.

637 Supplementary Table S1. $\mathrm{pH}$, specific conductivity and concentrations of the 638 flow-through column experiment of ISG-3 sample. 
Table 1. Main features of the studied ashes from 2011 Grímsvötn eruption. Mineral composition: ${ }^{* * *}$, prevalent; ${ }^{* *}$, common; *, frequent; $\left({ }^{*}\right)$, scarce; nd, not detected. Major oxides and loss on ignition (LOI) expressed as $\%, \mathrm{~m} / \mathrm{m}$. Trace elements expressed as $\mu \mathrm{g} / \mathrm{g}$.

\begin{tabular}{|c|c|c|c|c|c|c|c|c|c|}
\hline & ISG-0 & ISG-1 & ISG-2 & ISG-3 & ISG-4 & ISG-5 & ISG-6 & ISG-7 & ISG-8 \\
\hline Latitude & $63^{\circ} 47^{\prime} 222^{\prime \prime} \mathrm{N}$ & $63^{\circ} 40^{\prime} 18^{\prime \prime} \mathrm{N}$ & $63^{\circ} 47^{\prime} 38^{\prime \prime} \mathrm{N}$ & $63^{\circ} 47^{\prime} 38^{\prime \prime} \mathrm{N}$ & $63^{\circ} 54^{\prime} 40^{\prime \prime} \mathrm{N}$ & $63^{\circ} 57^{\prime} 23^{\prime \prime} \mathrm{N}$ & $63^{\circ} 57^{\prime} 23^{\prime \prime} \mathrm{N}$ & $63^{\circ} 57^{\prime} 23^{\prime \prime} \mathrm{N}$ & $63^{\circ} 57^{\prime} 23^{\prime \prime} \mathrm{N}$ \\
\hline Longitude & $18^{\circ} 03^{\prime} 02^{\prime \prime} \mathrm{W}$ & $18^{\circ} 24^{\prime} 13^{\prime \prime} \mathrm{W}$ & $18^{\circ} 02^{\prime} 17^{\prime \prime W}$ & $18^{\circ} 02^{\prime} 17^{\prime \prime W}$ & $17^{\circ} 43^{\prime} 14^{\prime \prime} \mathrm{W}$ & $17^{\circ} 26^{\prime} 58^{\prime \prime} \mathrm{W}$ & $17^{\circ} 26^{\prime} 58^{\prime \prime} \mathrm{W}$ & $17^{\circ} 26^{\prime} 58^{\prime \prime} \mathrm{W}$ & $17^{\circ} 26^{\prime} 58^{\prime \prime} \mathrm{W}$ \\
\hline Location & $\begin{array}{l}\text { Kirkjubæjar- } \\
\text { klaustur }\end{array}$ & Laki lava & $\begin{array}{l}\text { Skaftá river } \\
\text { (Kirkjubæjar- } \\
\text { klaustur) }\end{array}$ & $\begin{array}{l}\text { Skaftá river } \\
\text { (Kirkjubæjar- } \\
\text { klaustur) }\end{array}$ & $\begin{array}{l}\text { Brunná } \\
\text { river }\end{array}$ & Skeiðarársandur & Skeiðarársandur & Skeiðarársandur & Skeiðarársandur \\
\hline $\begin{array}{l}\text { Distance from } \\
\text { the vent }(\mathrm{km})\end{array}$ & 75 & 95 & 75 & 75 & 57 & 49 & 49 & 49 & 49 \\
\hline Thickness (cm) & 2 & $0-4$ & 8 & 30 & 24 & 25 & 10.5 & 10 & 0.5 \\
\hline Collection date & $22 / 05 / 2011$ & 25/05/2011 & $25 / 05 / 2011$ & $25 / 05 / 2011$ & 25/05/2011 & $25 / 05 / 2011$ & $25 / 05 / 2011$ & $25 / 05 / 2011$ & $25 / 05 / 2011$ \\
\hline Preservation & Pristine & Fresh & Fresh & Fresh & Fresh & Fresh & Fresh & Fresh & Fresh \\
\hline Glass & 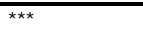 & 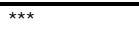 & 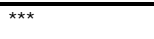 & 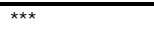 & 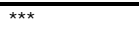 & $\star \star \star \star$ & $\star \star \star *$ & 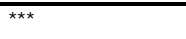 & 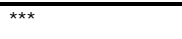 \\
\hline Augite & nd & nd & nd & nd & nd & ** & nd & nd & ** \\
\hline Anorthite & nd & nd & nd & nd & nd & * & nd & nd & * \\
\hline Pyrite & nd & nd & nd & nd & $(*)$ & nd & nd & nd & nd \\
\hline $\mathrm{SiO}_{2}$ & 56.14 & 52.49 & 52.23 & 50.94 & 54.49 & 52.07 & 51.40 & 55.80 & 55.25 \\
\hline $\mathrm{Al}_{2} \mathrm{O}_{3}$ & 12.26 & 12.78 & 12.64 & 13.53 & 12.73 & 12.99 & 14.01 & 11.88 & 12.94 \\
\hline $\mathrm{Fe}_{2} \mathrm{O}_{3}$ total & 12.70 & 13.45 & 13.50 & 13.62 & 13.28 & 12.60 & 13.21 & 12.44 & 12.19 \\
\hline $\mathrm{MnO}$ & 0.22 & 0.23 & 0.24 & 0.23 & 0.24 & 0.23 & 0.23 & 0.22 & 0.22 \\
\hline $\mathrm{MgO}$ & 4.99 & 5.04 & 5.17 & 5.22 & 4.94 & 5.73 & 4.99 & 4.63 & 5.92 \\
\hline $\mathrm{CaO}$ & 8.94 & 9.25 & 9.29 & 9.54 & 9.18 & 10.13 & 9.64 & 8.67 & 10.53 \\
\hline $\mathrm{Na}_{2} \mathrm{O}$ & 2.72 & 2.81 & 2.99 & 2.93 & 2.85 & 2.70 & 2.74 & 2.64 & 2.55 \\
\hline $\mathrm{K}_{2} \mathrm{O}$ & 0.47 & 0.49 & 0.49 & 0.50 & 0.51 & 0.43 & 0.47 & 0.47 & 0.42 \\
\hline $\mathrm{TiO}_{2}$ & 2.61 & 2.76 & 2.78 & 2.82 & 2.81 & 2.49 & 2.64 & 2.60 & 2.38 \\
\hline $\mathrm{P}_{2} \mathrm{O}_{5}$ & 0.38 & 0.39 & 0.38 & 0.38 & 0.38 & 0.32 & 0.37 & 0.35 & 0.29 \\
\hline LOI & -0.87 & -0.76 & -0.35 & -0.36 & -0.82 & -0.69 & -0.94 & -1.04 & 0.12 \\
\hline Total & 100.56 & 98.94 & 99.35 & 99.34 & 100.59 & 99.01 & 98.76 & 98.66 & 102.82 \\
\hline $\mathrm{Li}$ & 6.11 & 6.40 & 6.38 & 6.43 & 6.44 & 5.60 & 6.03 & 5.83 & 5.57 \\
\hline $\mathrm{Be}$ & 0.98 & 0.99 & 0.97 & 1.06 & 1.01 & 0.85 & 0.93 & 0.97 & 0.78 \\
\hline Sc & 36.8 & 37.8 & 38.5 & 39.4 & 38.1 & 42.1 & 39.8 & 36.2 & 42.5 \\
\hline V & 205 & 282 & 206 & 256 & 339 & 213 & 194 & 207 & 330 \\
\hline $\mathrm{Cr}$ & 37.7 & 33.6 & 43.4 & 28.9 & 37.3 & 78.4 & 52.4 & 41.9 & 78.0 \\
\hline Co & 36.5 & 37.5 & 37.4 & 38.7 & 37.8 & 39.6 & 37.9 & 35.7 & 39.3 \\
\hline $\mathrm{Ni}$ & 35.9 & 35.6 & 37.2 & 37.7 & 35.9 & 47.8 & 39.7 & 35.1 & 53.5 \\
\hline $\mathrm{Cu}$ & 92.1 & 92.3 & 92.3 & 93.4 & 91.2 & 108 & 96.1 & 86.8 & 118 \\
\hline $\mathrm{Zn}$ & 104 & 114 & 101 & 106 & 104 & 111 & 101 & 98.3 & 95.6 \\
\hline $\mathrm{Ga}$ & 17.6 & 18.2 & 17.9 & 18.0 & 17.9 & 18.2 & 18.1 & 17.2 & 17.9 \\
\hline $\mathrm{Ge}$ & 1.65 & 1.32 & 1.65 & 1.66 & 1.23 & 1.79 & 1.74 & 1.57 & 1.46 \\
\hline As & 0.24 & 0.16 & 0.33 & 0.36 & 0.11 & 0.18 & 0.21 & 0.25 & 0.11 \\
\hline $\mathrm{Rb}$ & 8.58 & 8.85 & 8.89 & 8.99 & 8.85 & 7.60 & 8.30 & 8.49 & 8.27 \\
\hline $\mathrm{Sr}$ & 195 & 202 & 209 & 216 & 212 & 198 & 205 & 195 & 202 \\
\hline Y & 37.4 & 39.6 & 40.6 & 41.1 & 40.8 & 35.7 & 38.4 & 38.0 & 34.4 \\
\hline $\mathrm{Zr}$ & 205 & 212 & 216 & 221 & 219 & 179 & 206 & 210 & 172 \\
\hline $\mathrm{Nb}$ & 19.9 & 20.6 & 20.0 & 20.0 & 20.5 & 17.1 & 19.1 & 18.4 & 15.5 \\
\hline Mo & 0.65 & 0.60 & 0.61 & 0.63 & 0.63 & 0.52 & 0.58 & 0.61 & 0.49 \\
\hline Sn & 1.14 & 1.16 & 1.20 & 1.20 & 1.17 & 1.07 & 1.10 & 1.18 & 1.09 \\
\hline $\mathrm{Sb}$ & 0.04 & 0.05 & 0.04 & 0.04 & 0.04 & 0.04 & 0.04 & 0.05 & 0.04 \\
\hline Cs & 0.08 & 0.09 & 0.09 & 0.09 & 0.09 & 0.08 & 0.08 & 0.09 & 0.07 \\
\hline $\mathrm{Ba}$ & 91.3 & 95.0 & 97.6 & 96.2 & 96.1 & 82.5 & 90.1 & 90.8 & 83.4 \\
\hline La & 14.5 & 14.7 & 15.2 & 15.2 & 15.4 & 13.0 & 14.5 & 13.8 & 12.4 \\
\hline $\mathrm{Ce}$ & 34.2 & 36.1 & 36.7 & 36.0 & 36.6 & 31.2 & 33.8 & 34.2 & 29.0 \\
\hline $\mathrm{Pr}$ & 4.89 & 5.11 & 5.07 & 5.15 & 5.23 & 4.32 & 4.79 & 4.83 & 4.18 \\
\hline $\mathrm{Nd}$ & 22.1 & 23.4 & 23.7 & 24.1 & 24.1 & 20.0 & 22.6 & 22.3 & 19.0 \\
\hline $\mathrm{Sm}$ & 6.06 & 6.41 & 6.48 & 6.69 & 6.48 & 5.53 & 6.14 & 6.06 & 5.57 \\
\hline Eu & 1.85 & 1.95 & 1.96 & 1.98 & 1.98 & 1.74 & 1.85 & 1.78 & 1.70 \\
\hline $\mathrm{Gd}$ & 6.59 & 6.98 & 6.99 & 7.23 & 7.21 & 6.08 & 6.72 & 6.62 & 6.08 \\
\hline $\mathrm{Tb}$ & 1.04 & 1.08 & 1.11 & 1.14 & 1.11 & 0.97 & 1.05 & 1.05 & 0.96 \\
\hline Dy & 6.75 & 6.92 & 7.12 & 7.08 & 7.15 & 6.21 & 6.66 & 6.65 & 6.20 \\
\hline $\mathrm{Ho}$ & 1.16 & 1.21 & 1.20 & 1.23 & 1.24 & 1.09 & 1.17 & 1.13 & 1.08 \\
\hline $\mathrm{Er}$ & 3.40 & 3.60 & 3.67 & 3.68 & 3.72 & 3.26 & 3.42 & 3.40 & 3.19 \\
\hline $\mathrm{Tm}$ & 0.57 & 0.60 & 0.61 & 0.62 & 0.62 & 0.55 & 0.58 & 0.58 & 0.54 \\
\hline $\mathrm{Yb}$ & 3.42 & 3.57 & 3.68 & 3.69 & 3.69 & 3.21 & 3.47 & 3.44 & 3.18 \\
\hline Lu & 0.53 & 0.55 & 0.57 & 0.57 & 0.56 & 0.48 & 0.52 & 0.52 & 0.49 \\
\hline $\mathrm{Hf}$ & 4.08 & 4.17 & 4.11 & 4.12 & 4.29 & 3.52 & 3.99 & 3.94 & 3.45 \\
\hline $\mathrm{Ta}$ & 1.01 & 1.03 & 1.00 & 1.04 & 1.07 & 0.85 & 0.93 & 0.95 & 0.82 \\
\hline W & 0.22 & 0.22 & 0.22 & 0.22 & 0.22 & 0.19 & 0.21 & 0.49 & 0.19 \\
\hline $\mathrm{TI}$ & 0.02 & 0.02 & 0.02 & 0.02 & 0.02 & 0.02 & 0.02 & 0.02 & 0.02 \\
\hline $\mathrm{Pb}$ & 1.28 & 1.25 & 1.32 & 1.24 & 1.21 & 1.21 & 1.40 & 1.14 & 1.18 \\
\hline $\mathrm{Bi}$ & 0.01 & 0.01 & 0.02 & 0.01 & 0.01 & 0.01 & 0.01 & 0.01 & 0.01 \\
\hline Th & 1.22 & 1.28 & 1.32 & 1.31 & 1.31 & 1.11 & 1.20 & 1.22 & 1.12 \\
\hline$U$ & 0.36 & 0.39 & 0.39 & 0.39 & 0.40 & 0.33 & 0.35 & 0.36 & 0.32 \\
\hline
\end{tabular}


Table 2. $\mathrm{pH}$ and specific conductivity (SC) of the batch leaching tests of Grímsvötn samples which

were monitored immediately after mixing the ash and the deionised water $\left(\mathrm{pH}_{0}\right.$ and $\left.\mathrm{SC}_{0}\right)$, and after

4 hours shaking $\left(\mathrm{pH}_{\mathrm{f}}\right.$ and $\left.\mathrm{SC}_{\mathrm{f}}\right)$ without filtering. $\mathrm{SC}$ is expressed as $\mu \mathrm{S} / \mathrm{cm}$.

\begin{tabular}{|c|c|c|c|c|c|c|c|c|c|c|}
\hline Parameter & Unit & ISG-0 & ISG-1 & ISG-2 & ISG-3 & ISG-4 & ISG-5 & ISG-6 & ISG-7 & ISG-8 \\
\hline $\mathrm{pH}_{0}$ & $\mathrm{pH}$ unit & 7.62 & 7.20 & 6.65 & 6.80 & 7.20 & 6.12 & 6.00 & 6.10 & 5.80 \\
\hline $\mathrm{pH}_{\mathrm{f}}$ & $\mathrm{pH}$ unit & 8.93 & 8.84 & 7.75 & 8.22 & 9.26 & 7.68 & 8.17 & 8.84 & 7.33 \\
\hline $\mathrm{SC}_{0}$ & $\mu \mathrm{S} / \mathrm{cm}$ & 90 & 117 & 356 & 101 & 43 & 18 & 86 & 96 & 7 \\
\hline $\mathrm{SC}_{\mathrm{f}}$ & $\mu \mathrm{S} / \mathrm{cm}$ & 244 & 148 & 404 & 122 & 100 & 28 & 110 & 130 & 15 \\
\hline $\mathrm{Ca}$ & $\mathrm{mg} / \mathrm{l}$ & 2.04 & 1.77 & 3.62 & 1.22 & 1.03 & 0.64 & 0.89 & 1.26 & 0.42 \\
\hline $\mathrm{Mg}$ & $\mathrm{mg} / \mathrm{l}$ & 0.23 & 0.16 & 0.54 & 0.14 & 0.11 & 0.10 & 0.13 & 0.13 & 0.06 \\
\hline $\mathrm{Na}$ & $\mathrm{mg} / \mathrm{l}$ & 1.39 & 0.80 & 2.41 & 0.71 & 0.58 & 0.25 & 0.70 & 0.72 & 0.24 \\
\hline K & $\mathrm{mg} / \mathrm{l}$ & 0.11 & 0.11 & 0.13 & 0.10 & 0.08 & 0.11 & 0.10 & 0.07 & 0.11 \\
\hline $\mathrm{Si}$ & $\mathrm{mg} / \mathrm{l}$ & 0.18 & 0.21 & 0.15 & 0.12 & 0.11 & 0.17 & 0.11 & 0.13 & 0.15 \\
\hline $\mathrm{Cl}$ & $\mathrm{mg} / \mathrm{l}$ & 0.29 & 0.15 & 0.54 & 0.15 & 0.11 & 0.10 & 0.13 & 0.15 & 0.10 \\
\hline $\mathrm{SO}_{4}$ & $\mathrm{mg} / \mathrm{l}$ & 6.02 & 3.47 & 12.80 & 2.89 & 2.42 & 0.63 & 2.80 & 3.15 & 0.34 \\
\hline$F$ & $\mathrm{mg} / \mathrm{l}$ & 1.73 & 0.90 & 1.37 & 0.71 & 0.81 & 0.08 & 0.58 & 0.88 & 0.02 \\
\hline Li & $\mu \mathrm{g} / \mathrm{l}$ & 0.61 & 0.39 & 0.81 & 0.30 & 0.27 & 0.11 & 0.34 & 0.33 & 0.11 \\
\hline $\mathrm{Be}$ & $\mu \mathrm{g} / \mathrm{l}$ & 0.01 & 0.02 & 0.01 & 0.01 & 0.01 & 0.01 & 0.01 & 0.01 & 0.02 \\
\hline B & $\mu \mathrm{g} / \mathrm{l}$ & 27.6 & 26.0 & 17.2 & 17.9 & 19.3 & 24.3 & 29.2 & 17.8 & 27.2 \\
\hline $\mathrm{Al}$ & $\mu \mathrm{g} / \mathrm{l}$ & 180.7 & 372.5 & 188.4 & 168.1 & 201.7 & 264.3 & 223.6 & 183.4 & 272.7 \\
\hline$P$ & $\mu g / l$ & 23.4 & 35.0 & 21.1 & 19.8 & 18.1 & 19.2 & 13.8 & 19.3 & 17.6 \\
\hline Sc & $\mu \mathrm{g} / \mathrm{l}$ & 0.07 & 0.11 & 0.06 & 0.06 & 0.06 & 0.08 & 0.05 & 0.06 & 0.06 \\
\hline $\mathrm{Ti}$ & $\mu \mathrm{g} / \mathrm{l}$ & 6.54 & 19.00 & 7.52 & 6.06 & 8.76 & 11.93 & 8.11 & 8.47 & 8.49 \\
\hline V & $\mu \mathrm{g} / \mathrm{l}$ & 0.91 & 1.50 & 0.72 & 0.63 & 0.71 & 0.65 & 0.57 & 0.80 & 0.62 \\
\hline $\mathrm{Cr}$ & $\mu \mathrm{g} / \mathrm{l}$ & 0.08 & 0.12 & 0.09 & 0.13 & 0.10 & 0.23 & 0.11 & 0.07 & 0.17 \\
\hline $\mathrm{Fe}$ & $\mu \mathrm{g} / \mathrm{l}$ & 173.9 & 382.9 & 187.8 & 135.9 & 173.6 & 195.1 & 138.8 & 184.6 & 130.7 \\
\hline $\mathrm{Mn}$ & $\mu \mathrm{g} / \mathrm{l}$ & 11.40 & 14.69 & 12.54 & 10.71 & 8.43 & 5.08 & 6.53 & 8.65 & 2.93 \\
\hline Co & $\mu \mathrm{g} / \mathrm{l}$ & 0.11 & 0.17 & 0.07 & 0.08 & 0.09 & 0.07 & 0.08 & 0.09 & 0.05 \\
\hline $\mathrm{Ni}$ & $\mu \mathrm{g} / \mathrm{l}$ & 0.66 & 0.79 & 0.52 & 0.80 & 0.57 & 0.39 & 0.56 & 0.48 & 0.72 \\
\hline $\mathrm{Cu}$ & $\mu \mathrm{g} / \mathrm{l}$ & 2.45 & 6.87 & 3.64 & 2.69 & 3.12 & 1.95 & 2.27 & 3.09 & 1.61 \\
\hline $\mathrm{Zn}$ & $\mu \mathrm{g} / \mathrm{l}$ & 4.29 & 5.11 & 4.94 & 5.21 & 3.70 & 4.00 & 3.70 & 3.12 & 7.07 \\
\hline $\mathrm{Ga}$ & $\mu g / l$ & 0.08 & 0.12 & 0.06 & 0.05 & 0.06 & 0.05 & 0.06 & 0.07 & 0.04 \\
\hline $\mathrm{Ge}$ & $\mu \mathrm{g} / \mathrm{l}$ & 0.02 & 0.02 & 0.02 & 0.01 & 0.01 & 0.02 & 0.02 & 0.01 & 0.01 \\
\hline As & $\mu \mathrm{g} / \mathrm{l}$ & 0.03 & 0.10 & 0.03 & 0.03 & 0.07 & 0.03 & 0.13 & 0.04 & 0.10 \\
\hline $\mathrm{Se}$ & $\mu \mathrm{g} / \mathrm{l}$ & 1.92 & 2.08 & 1.10 & 1.00 & 0.76 & 1.31 & -0.21 & 1.33 & 1.46 \\
\hline $\mathrm{Rb}$ & $\mu \mathrm{g} / \mathrm{l}$ & 0.10 & 0.12 & 0.13 & 0.09 & 0.08 & 0.09 & 0.08 & 0.08 & 0.07 \\
\hline $\mathrm{Sr}$ & $\mu \mathrm{g} / \mathrm{l}$ & 4.89 & 3.85 & 8.00 & 2.92 & 2.33 & 2.05 & 2.06 & 2.90 & 1.22 \\
\hline$Y$ & $\mu \mathrm{g} / \mathrm{l}$ & 0.36 & 0.51 & 0.33 & 0.27 & 0.25 & 0.35 & 0.17 & 0.29 & 0.23 \\
\hline $\mathrm{Zr}$ & $\mu \mathrm{g} / \mathrm{l}$ & 0.13 & 0.18 & 0.13 & 0.12 & 0.14 & 0.13 & 0.24 & 0.10 & 0.20 \\
\hline $\mathrm{Nb}$ & $\mu \mathrm{g} / \mathrm{l}$ & 0.04 & 0.04 & 0.04 & 0.04 & 0.03 & 0.04 & 0.04 & 0.03 & 0.04 \\
\hline Mo & $\mu \mathrm{g} / \mathrm{l}$ & 0.05 & 0.04 & 0.06 & 0.03 & 0.02 & 0.02 & 0.02 & 0.03 & 0.02 \\
\hline $\mathrm{Ag}$ & $\mu \mathrm{g} / \mathrm{l}$ & 0.02 & 0.02 & 0.02 & 0.03 & 0.02 & 0.02 & 0.02 & 0.01 & 0.02 \\
\hline $\mathrm{Cd}$ & $\mu \mathrm{g} / \mathrm{l}$ & 0.02 & 0.02 & 0.02 & 0.02 & 0.01 & 0.01 & 0.01 & 0.01 & 0.01 \\
\hline Sn & $\mu \mathrm{g} / \mathrm{l}$ & 0.95 & 0.86 & 1.05 & 1.31 & 0.80 & 1.10 & 0.87 & 0.60 & 0.96 \\
\hline $\mathrm{Sb}$ & $\mu \mathrm{g} / \mathrm{l}$ & 0.014 & 0.005 & 0.007 & 0.007 & 0.004 & 0.005 & 0.003 & 0.006 & 0.009 \\
\hline I & $\mu \mathrm{g} / \mathrm{l}$ & 0.27 & 0.29 & 0.24 & 0.22 & 0.19 & 0.22 & 0.20 & 0.18 & 0.19 \\
\hline Cs & $\mu \mathrm{g} / \mathrm{l}$ & 0.003 & 0.002 & 0.002 & 0.002 & 0.002 & 0.002 & 0.002 & 0.002 & 0.002 \\
\hline $\mathrm{Ba}$ & $\mu \mathrm{g} / \mathrm{l}$ & 0.67 & 0.67 & 0.68 & 0.57 & 0.45 & 0.60 & 0.47 & 0.44 & 0.52 \\
\hline $\mathrm{La}$ & $\mu \mathrm{g} / \mathrm{l}$ & 0.160 & 0.224 & 0.145 & 0.117 & 0.111 & 0.165 & 0.081 & 0.127 & 0.111 \\
\hline $\mathrm{Ce}$ & $\mu \mathrm{g} / \mathrm{l}$ & 0.387 & 0.526 & 0.313 & 0.274 & 0.260 & 0.356 & 0.185 & 0.303 & 0.240 \\
\hline $\mathrm{Pr}$ & $\mu \mathrm{g} / \mathrm{l}$ & 0.054 & 0.074 & 0.045 & 0.039 & 0.036 & 0.051 & 0.025 & 0.042 & 0.034 \\
\hline $\mathrm{Nd}$ & $\mu \mathrm{g} / \mathrm{l}$ & 0.253 & 0.359 & 0.211 & 0.174 & 0.173 & 0.249 & 0.122 & 0.203 & 0.164 \\
\hline $\mathrm{Sm}$ & $\mu \mathrm{g} / \mathrm{l}$ & 0.062 & 0.097 & 0.056 & 0.049 & 0.046 & 0.057 & 0.030 & 0.053 & 0.041 \\
\hline $\mathrm{Eu}$ & $\mu \mathrm{g} / \mathrm{l}$ & 0.022 & 0.029 & 0.019 & 0.014 & 0.014 & 0.018 & 0.010 & 0.017 & 0.012 \\
\hline $\mathrm{Gd}$ & $\mu \mathrm{g} / \mathrm{l}$ & 0.076 & 0.105 & 0.065 & 0.050 & 0.049 & 0.065 & 0.032 & 0.060 & 0.045 \\
\hline $\mathrm{Tb}$ & $\mu \mathrm{g} / \mathrm{l}$ & 0.014 & 0.018 & 0.012 & 0.010 & 0.009 & 0.013 & 0.007 & 0.011 & 0.008 \\
\hline Dy & $\mu \mathrm{g} / \mathrm{l}$ & 0.078 & 0.111 & 0.059 & 0.053 & 0.052 & 0.069 & 0.032 & 0.063 & 0.047 \\
\hline $\mathrm{Ho}$ & $\mu \mathrm{g} / \mathrm{l}$ & 0.014 & 0.019 & 0.012 & 0.010 & 0.009 & 0.012 & 0.006 & 0.011 & 0.009 \\
\hline $\mathrm{Er}$ & $\mu \mathrm{g} / \mathrm{l}$ & 0.038 & 0.055 & 0.034 & 0.026 & 0.026 & 0.036 & 0.017 & 0.031 & 0.025 \\
\hline $\mathrm{Tm}$ & $\mu \mathrm{g} / \mathrm{l}$ & 0.005 & 0.007 & 0.004 & 0.003 & 0.003 & 0.005 & 0.002 & 0.004 & 0.003 \\
\hline $\mathrm{Yb}$ & $\mu \mathrm{g} / \mathrm{l}$ & 0.031 & 0.041 & 0.024 & 0.021 & 0.020 & 0.028 & 0.014 & 0.024 & 0.020 \\
\hline Lu & $\mu \mathrm{g} / \mathrm{l}$ & 0.004 & 0.006 & 0.004 & 0.003 & 0.003 & 0.005 & 0.002 & 0.003 & 0.003 \\
\hline $\mathrm{Hf}$ & $\mu \mathrm{g} / \mathrm{l}$ & 0.017 & 0.017 & 0.012 & 0.011 & 0.011 & 0.011 & 0.015 & 0.011 & 0.013 \\
\hline $\mathrm{Ta}$ & $\mu \mathrm{g} / \mathrm{l}$ & 0.010 & 0.012 & 0.010 & 0.010 & 0.009 & 0.011 & 0.011 & 0.007 & 0.010 \\
\hline W & $\mu \mathrm{g} / \mathrm{l}$ & 0.06 & 0.06 & 0.06 & 0.12 & 0.06 & 0.07 & 0.06 & 0.04 & 0.06 \\
\hline $\mathrm{Hg}$ & $\mu \mathrm{g} / \mathrm{l}$ & 0.022 & 0.009 & 0.007 & 0.008 & 0.006 & 0.001 & 0.006 & 0.010 & 0.001 \\
\hline $\mathrm{Tl}$ & $\mu \mathrm{g} / \mathrm{l}$ & 0.003 & 0.004 & 0.003 & 0.003 & 0.003 & 0.003 & 0.003 & 0.002 & 0.003 \\
\hline $\mathrm{Pb}$ & $\mu \mathrm{g} / \mathrm{l}$ & 0.22 & 0.30 & 0.42 & 0.35 & 0.25 & 0.25 & 0.29 & 0.17 & 0.28 \\
\hline $\mathrm{Bi}$ & $\mu \mathrm{g} / \mathrm{l}$ & 0.004 & 0.004 & 0.003 & 0.003 & 0.003 & 0.003 & 0.003 & 0.003 & 0.003 \\
\hline Th & $\mu \mathrm{g} / \mathrm{l}$ & 0.013 & 0.013 & 0.013 & 0.008 & 0.008 & 0.008 & 0.010 & 0.009 & 0.008 \\
\hline U & $\mu \mathrm{g} / \mathrm{l}$ & 0.003 & 0.010 & 0.003 & 0.004 & 0.007 & 0.005 & 0.011 & 0.004 & 0.010 \\
\hline
\end{tabular}


Table 3. Potential geochemical fluxes associated with the 2011 Grímsvötn eruption. Data of batch ( $1 \mathrm{~g}$ of volcanic ash was contacted with $10 \mathrm{ml}$ of deionized water during $4 \mathrm{~h}$ ) and column leaching (10 $\mathrm{g}$ of ash were leached in a flow-through column with $1000 \mathrm{ml}$ of deionized water pumped at $0.12 \mathrm{ml} / \mathrm{min}$ ) experiments are reported for the same sample (ISG-3), chosen for its representativeness. Batch results are compared with an average of ash batch tests (Ayris and Delmelle, 2012), sample $\mathrm{CH}-1 \mathrm{~F}$ of 2008 Chaitén eruption (Ruggieri et al., 2012a), and mean values of samples from the first eruptive phase of 2010 Eyjafjallajökull eruption (Bagnato et al., 2013). nd, not determined; <LoD, lower than limit of detection.

\begin{tabular}{|c|c|c|c|c|c|c|c|c|c|c|c|c|c|}
\hline \multirow{4}{*}{ Element } & \multirow{2}{*}{\multicolumn{5}{|c|}{$\begin{array}{l}\text { Batch leached fraction average } \\
\text { Ayris and Delmelle } 2012\end{array}$}} & \multicolumn{3}{|c|}{ Batch leached fraction } & \multirow{2}{*}{\multicolumn{5}{|c|}{$\begin{array}{c}\text { Grímsvötn } 2011 \\
\text { this work }\end{array}$}} \\
\hline & & & & & & \multirow{3}{*}{$\begin{array}{c}\text { Chaitén } 2008 \\
\text { Ruggieri et al. } 2012 \\
\mathrm{mg} / \mathrm{kg}\end{array}$} & \multirow{3}{*}{$\begin{array}{c}\text { Eyjafjallajökull } 2010 \\
\text { Bagnato et al. } 2012 \\
\mathrm{mg} / \mathrm{kg}\end{array}$} & \multirow{3}{*}{$\begin{array}{c}\text { Grímsvötn } 2011 \\
\text { this work } \\
\mathrm{mg} / \mathrm{kg}\end{array}$} & & & & & \\
\hline & & & & & Count & & & & \multirow{2}{*}{$\begin{array}{c}\text { Bulk mass } \\
\mathrm{mt}\end{array}$} & \multicolumn{2}{|c|}{ Leachable mass (batch) } & Leacha & mass (column) \\
\hline & $\operatorname{Max}$ & Min & Mean & Median & courit & & & & & $\mathrm{mt}$ & \% of bulk (RML) & $\mathrm{mt}$ & $\%$ of batch \\
\hline $\mathrm{Ca}$ & 23,590 & $<1$ & 2,172 & 2,140 & 27 & 80.0 & 99.8 & 12.22 & $49,299,716$ & 8908 & 0.0181 & 2034 & 22.8 \\
\hline $\mathrm{s}$ & 17,770 & $<1$ & 1,711 & 1,662 & 30 & 51.1 & 30.9 & 9.63 & nd & 7021 & & 973 & 13.9 \\
\hline $\mathrm{Na}$ & 2,560 & $<1$ & 407 & 378 & 28 & 64.2 & 151 & 7.13 & $14,977,060$ & 5198 & 0.0347 & 914 & 17.6 \\
\hline $\mathrm{F}$ & 3,140 & $<1$ & 135 & 129 & 29 & 6.80 & 31.9 & 7.13 & nd & 5194 & & nd & \\
\hline Al & 1,164 & $<1$ & 63 & 58 & 24 & 4.95 & 1.79 & 1.68 & $49,623,245$ & 1225 & 0.0025 & 446 & 36.4 \\
\hline $\mathrm{Cl}$ & 11,160 & 5 & 1,189 & 1,162 & 30 & 148 & 116 & 1.50 & nd & 1094 & & 140 & 12.8 \\
\hline $\mathrm{Mg}$ & 4,240 & $<1$ & 349 & 335 & 27 & 6.57 & 5.47 & 1.36 & $22,780,688$ & 991 & 0.0044 & 257 & 25.9 \\
\hline $\mathrm{Fe}$ & 606 & $<1$ & 24 & 21 & 24 & $<L O D$ & 0.76 & 1.36 & $66,279,957$ & 991 & 0.0015 & 374 & 37.8 \\
\hline $\mathrm{Si}$ & 390 & $<1$ & 27 & 25 & 24 & 18.4 & nd & 1.18 & $182,045,381$ & 860 & 0.0005 & 817 & 95.0 \\
\hline $\mathrm{K}$ & 788 & $<1$ & 76 & 71 & 26 & 14.2 & 17.7 & 1.02 & $2,863,742$ & 744 & 0.0260 & 82.2 & 11.1 \\
\hline P & 724 & $<1$ & 74 & 74 & 12 & 0.37 & nd & 0.20 & $1,145,187$ & 145 & 0.0126 & 19.5 & 13.5 \\
\hline B & 7.72 & 0.00 & 2.69 & 2.61 & 9 & $<L O D$ & 0.05 & 0.18 & nd & 130 & & nd & \\
\hline $\mathrm{Mn}$ & 144 & $<1$ & 22 & 20 & 22 & 0.47 & 0.46 & 0.107 & $1,291,854$ & 78.1 & 0.0060 & 7.72 & 9.9 \\
\hline $\mathrm{Ti}$ & 18.67 & $<0.001$ & 2.32 & 2.32 & 12 & 0.09 & 0.05 & 0.061 & $11,601,750$ & 44.1 & 0.0004 & 38.5 & 87.2 \\
\hline $\mathrm{Zn}$ & 53.02 & $<0.10$ & 4.01 & 3.58 & 21 & 0.17 & 0.42 & 0.052 & 75,643 & 38.0 & 0.0502 & 3.01 & 7.9 \\
\hline $\mathrm{Sr}$ & 35.05 & 0.38 & 4.63 & 4.30 & 14 & 0.15 & 0.16 & 0.029 & 148,482 & 21.3 & 0.0143 & 4.16 & 19.6 \\
\hline $\mathrm{Cu}$ & 95 & $<1$ & 6 & 5 & 22 & 0.04 & 0.07 & 0.027 & 70,503 & 19.6 & 0.0278 & 1.05 & 5.3 \\
\hline Sn & 0.119 & 0.008 & 0.079 & 0.079 & 11 & nd & nd & 0.013 & 835 & 9.51 & 1.1396 & 0.180 & 1.9 \\
\hline $\mathrm{Se}$ & 0.550 & $<0.025$ & 0.059 & 0.055 & 14 & nd & 0.01 & 0.010 & nd & 7.25 & & 1.61 & 22.1 \\
\hline $\mathrm{Ni}$ & 3.90 & $<0.10$ & 0.52 & 0.50 & 14 & 0.05 & 0.03 & 0.008 & 29,038 & 5.85 & 0.0202 & 0.642 & 11.0 \\
\hline V & 0.300 & $<0.10$ & 0.091 & 0.089 & 14 & 0.01 & 0.05 & 0.006 & 180,735 & 4.57 & 0.0025 & 3.16 & 69.2 \\
\hline $\mathrm{Ba}$ & 6.70 & $<0.10$ & 0.94 & 0.94 & 14 & 0.09 & 0.05 & 0.006 & 66,662 & 4.16 & 0.0062 & 0.600 & 14.4 \\
\hline $\mathrm{Pb}$ & 2.07 & $<0.050$ & 0.14 & 0.11 & 16 & 0.35 & 0.008 & 0.003 & 908 & 2.53 & 0.2786 & 0.110 & 4.4 \\
\hline $\mathrm{Li}$ & 1.88 & $<0.001$ & 0.27 & 0.22 & 14 & 0.10 & 0.06 & 0.003 & 4,438 & 2.18 & 0.0491 & 0.376 & 17.2 \\
\hline $\mathrm{Ce}$ & 0.110 & $<0.010$ & 0.063 & 0.063 & 5 & 0.00 & nd & 0.003 & 24,936 & 2.00 & 0.0080 & 0.119 & 6.0 \\
\hline Y & 1.000 & 0.001 & 0.035 & 0.029 & 6 & $<L O D$ & nd & 0.003 & 28,031 & 1.94 & 0.0069 & 0.111 & 5.7 \\
\hline 1 & & & & & & nd & nd & 0.002 & nd & 1.63 & & 0.041 & 2.5 \\
\hline $\mathrm{Nd}$ & 0.042 & 0.008 & 0.022 & 0.022 & 5 & nd & nd & 0.002 & 16,309 & 1.27 & 0.0078 & 0.076 & 6.0 \\
\hline $\mathrm{Cr}$ & 0.52 & $<0.050$ & 0.10 & 0.10 & 13 & 0.01 & 0.02 & 0.001 & 34,957 & 0.94 & 0.0027 & 0.289 & 30.8 \\
\hline $\mathrm{Zr}$ & $<0.001$ & $<0.001$ & 0.0020 & 0.0020 & 6 & 0.01 & nd & 0.001 & 149,009 & 0.87 & 0.0006 & 0.281 & 32.4 \\
\hline La & 0.200 & $<0.10$ & 0.042 & 0.041 & 6 & nd & nd & 0.001 & 10,428 & 0.85 & 0.0082 & 0.050 & 5.9 \\
\hline W & 0.0110 & 0.002 & 0.0060 & 0.0060 & 5 & nd & nd & 0.0012 & 178 & 0.85 & 0.4785 & 0.024 & 2.8 \\
\hline $\mathrm{Rb}$ & 0.240 & $<0.015$ & 0.083 & 0.083 & 6 & 0.03 & nd & 0.0009 & 6,222 & 0.67 & 0.0108 & 0.076 & 11.4 \\
\hline Co & 1.30 & $<0.010$ & 0.20 & 0.19 & 16 & $<\mathrm{LOD}$ & 0.001 & 0.0008 & 27,578 & 0.60 & 0.0022 & 0.146 & 24.4 \\
\hline Sc & & & & & & 0.02 & nd & 0.0006 & 28,441 & 0.40 & 0.0014 & 0.092 & 22.9 \\
\hline Dy & 0.0050 & $<0.001$ & 0.0020 & 0.0020 & 5 & nd & nd & 0.0005 & 4,919 & 0.39 & 0.0079 & 0.024 & 6.2 \\
\hline $\mathrm{Gd}$ & 0.0070 & $<0.001$ & 0.0040 & 0.0040 & 5 & nd & nd & 0.0005 & 4,900 & 0.36 & 0.0074 & 0.021 & 5.7 \\
\hline $\mathrm{Ga}$ & 0.033 & 0.006 & 0.013 & 0.013 & 5 & nd & nd & 0.0005 & 13,050 & 0.36 & 0.0027 & 0.197 & 55.3 \\
\hline Sm & 0.0060 & $<0.001$ & 0.0030 & 0.0030 & 5 & nd & nd & 0.0005 & 4,489 & 0.36 & 0.0080 & 0.020 & 5.6 \\
\hline $\mathrm{Pr}$ & 0.0100 & $<0.001$ & 0.0050 & 0.0050 & 5 & nd & nd & 0.0004 & 3,529 & 0.28 & 0.0081 & 0.016 & 5.7 \\
\hline $\mathrm{Nb}$ & $<0.001$ & $<0.001$ & $<0.001$ & $<0.001$ & 5 & 0.05 & nd & 0.0004 & 13,864 & 0.26 & 0.0019 & 0.025 & 9.4 \\
\hline Mo & 0.620 & $<0.040$ & 0.069 & 0.063 & 12 & 0.02 & 0.02 & 0.0003 & 430 & 0.23 & 0.0543 & 0.036 & 15.5 \\
\hline $\mathrm{Ag}$ & 1.0790 & $<0.001$ & 0.0070 & 0.0010 & 5 & nd & nd & 0.0003 & nd & 0.23 & & 0.012 & 5.5 \\
\hline $\mathrm{Er}$ & 0.0020 & $<0.001$ & 0.0010 & 0.0010 & 5 & nd & nd & 0.0003 & 2,539 & 0.19 & 0.0075 & 0.013 & 6.8 \\
\hline As & 9.33 & $<0.10$ & 0.16 & 0.13 & 13 & 0.35 & 0.01 & 0.0003 & 158 & 0.18 & 0.1153 & 0.033 & 17.9 \\
\hline $\mathrm{Yb}$ & $<0.001$ & $<0.001$ & $<0.001$ & $<0.001$ & 5 & nd & nd & 0.0002 & 2,539 & 0.15 & 0.0060 & 0.010 & 6.8 \\
\hline $\mathrm{Cd}$ & 0.337 & $<0.004$ & 0.057 & 0.053 & 15 & nd & 0.002 & 0.00018 & nd & 0.13 & & 0.007 & 5.1 \\
\hline Eu & $<0.001$ & $<0.001$ & 0.0000 & 0.0000 & 5 & nd & nd & 0.0001 & 1,361 & 0.10 & 0.0075 & 0.007 & 6.5 \\
\hline Ge & 0.0080 & $<0.001$ & 0.0030 & 0.0030 & 5 & nd & nd & 0.0001 & 1,140 & 0.10 & 0.0090 & 0.034 & 32.9 \\
\hline $\mathrm{Be}$ & 0.0160 & $<0.001$ & 0.0050 & 0.0050 & 6 & nd & nd & 0.00011 & 692 & 0.080 & 0.0116 & 0.009 & 10.6 \\
\hline $\mathrm{Hf}$ & 0.189 & $<0.001$ & 0.079 & 0.079 & 5 & nd & nd & 0.00011 & 2,890 & 0.08 & 0.0028 & 0.009 & 10.7 \\
\hline Ho & $<0.001$ & $<0.001$ & 0.0010 & 0.0010 & 5 & nd & nd & 0.00010 & 851 & 0.073 & 0.0086 & 0.005 & 6.2 \\
\hline $\mathrm{Ta}$ & 0.025 & $<0.001$ & 0.010 & 0.010 & 5 & nd & nd & 0.00010 & 704 & 0.073 & 0.0104 & 0.004 & 5.9 \\
\hline $\mathrm{Tb}$ & $<0.001$ & $<0.001$ & 0.0010 & 0.0010 & 5 & nd & nd & 0.00010 & 771 & 0.073 & 0.0095 & 0.004 & 5.7 \\
\hline $\mathrm{Hg}$ & 0.0090 & $<0.001$ & 0.0000 & 0.0000 & 11 & nd & nd & 0.00008 & nd & 0.058 & & 0.003 & 5.7 \\
\hline Th & $<0.001$ & $<0.001$ & 0.0010 & 0.0010 & 5 & nd & 0.0003 & 0.00008 & 898 & 0.058 & 0.0065 & 0.004 & 6.7 \\
\hline $\mathrm{Sb}$ & 0.070 & $<0.010$ & 0.024 & 0.024 & 7 & 0.00 & 0.001 & 0.00007 & 31 & 0.051 & 0.1662 & 0.005 & 9.8 \\
\hline U & 0.0120 & $<0.001$ & 0.0020 & 0.0020 & 9 & nd & 0.0004 & 0.00004 & 5,739 & 0.029 & 0.0005 & 0.002 & 7.7 \\
\hline $\mathrm{Bi}$ & 0.150 & $<0.005$ & 0.014 & 0.015 & 11 & nd & nd & 0.00003 & 9 & 0.022 & 0.2523 & 0.002 & 7.3 \\
\hline Lu & $<0.001$ & $<0.001$ & $<0.001$ & $<0.001$ & 5 & nd & nd & 0.00003 & 387 & 0.022 & 0.0057 & 0.002 & 7.6 \\
\hline $\mathrm{Tl}$ & 0.1200 & $<0.001$ & 0.0060 & 0.0040 & 7 & nd & nd & 0.00003 & 15 & 0.022 & 0.1467 & 0.002 & 7.8 \\
\hline $\mathrm{Tm}$ & $<0.001$ & $<0.001$ & 0.0010 & 0.0010 & 5 & nd & nd & 0.00003 & 426 & 0.022 & 0.0051 & 0.002 & 8.1 \\
\hline Cs & 0.033 & 0.001 & 0.008 & 0.008 & 5 & 0.00 & 0.0004 & 0.00002 & 62 & 0.015 & 0.0236 & 0.002 & 13.0 \\
\hline
\end{tabular}



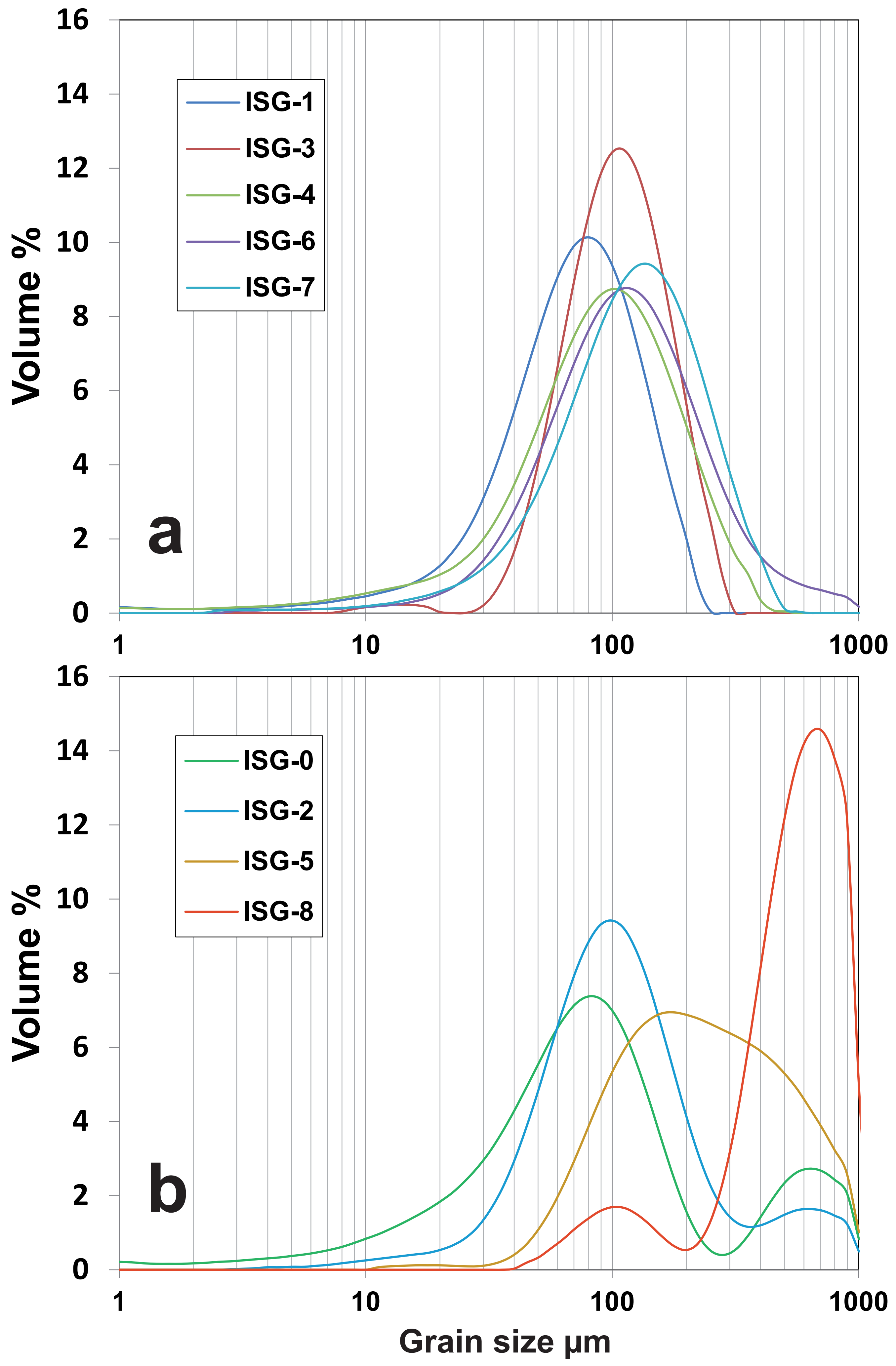


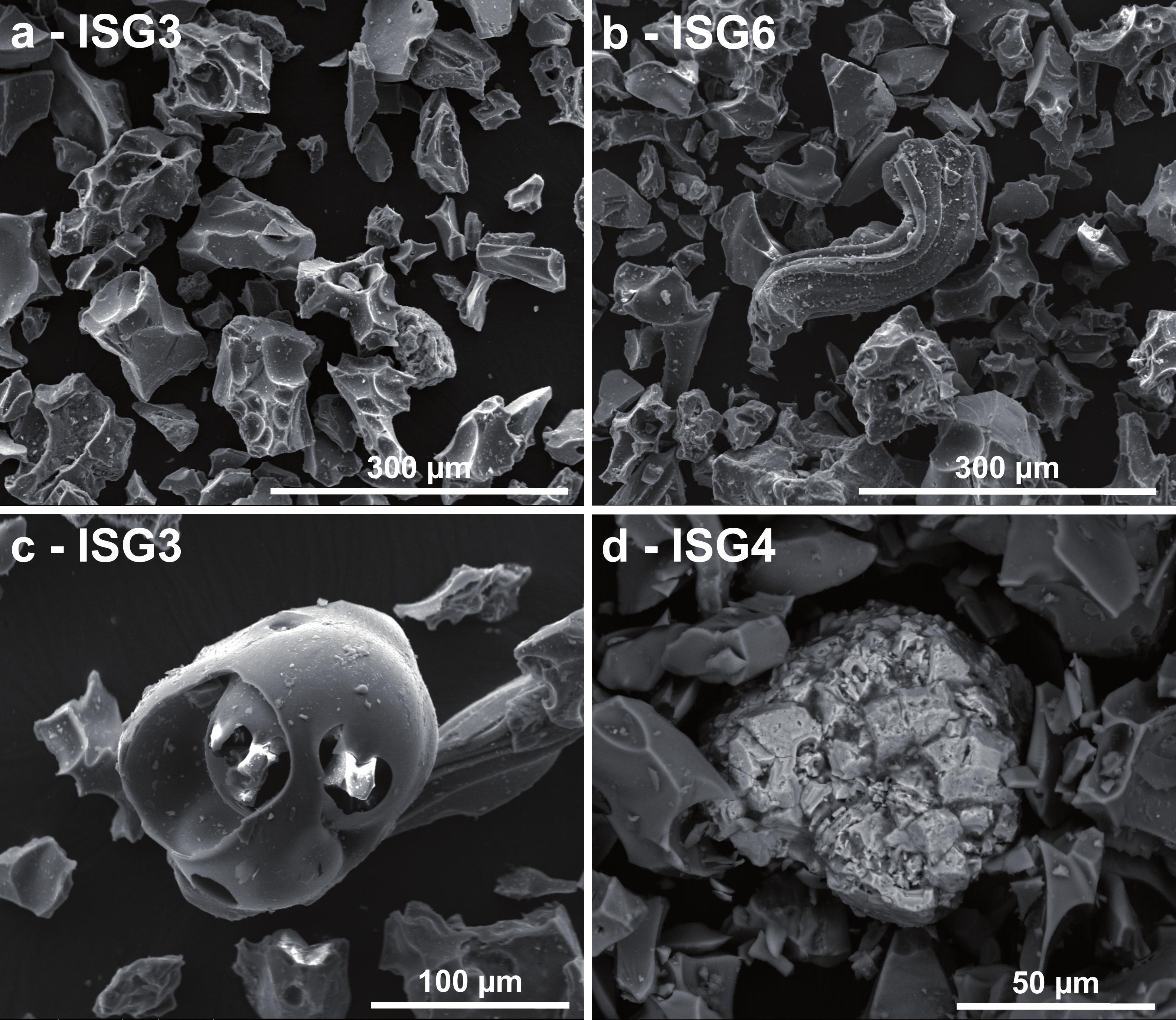




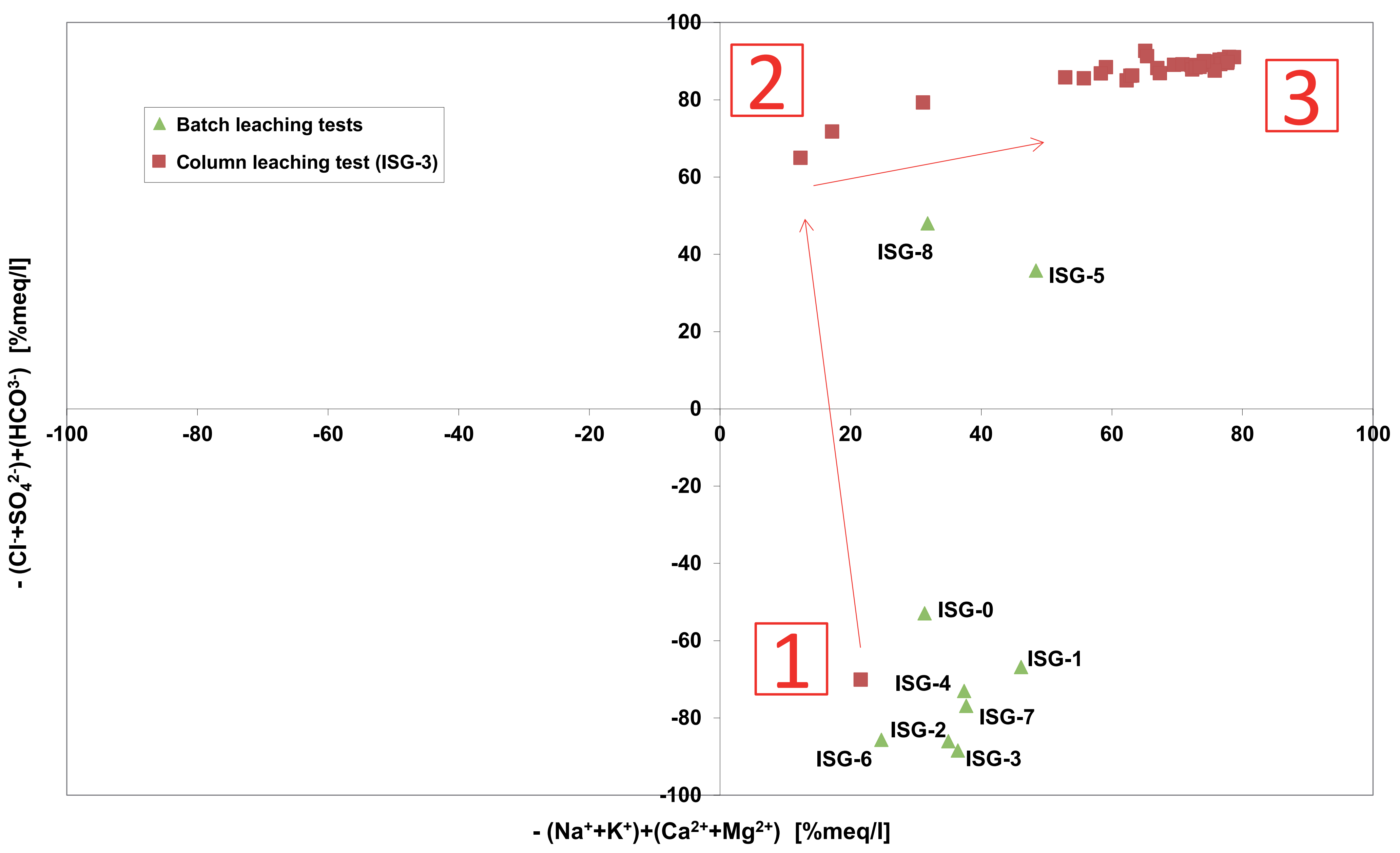




\section{Supplementary material - Details on analytical methods}

Particle size distributions were obtained using a laser diffractometer (Malvern Mastersizer 2000 Hidro-Mu) at the X-ray Diffraction Service of the Institute of Earth Sciences Jaume Almera (ICTJA-CSIC), Spain. It allows the measurement of particles in a range of $0.1-1000 \mu \mathrm{m}$. For each sample, the results are the average of 3 cycles of $8 \mathrm{~s}$ each. The samples were dispersed in Milli-Q plus ultrapure water type $(18.2 \mathrm{M} \Omega / \mathrm{cm})$. The pump speed was $2500 \mathrm{rpm}$. A refractive index of 1.52 and absorption of 0.1 were used in the determinations (Blott et al. 2004). The obscuration is $10-20 \%$. Results were then plotted with GRADISTAT (Blott \&Pye 2001).

The scanning electron microscope (SEM) analysis was performed with a FEI Quanta 200 ESEM FEG equipped with an Energy Dispersive X-Ray (EDX) system and the GENESIS software for a semi-quantitative chemical analysis (minimum spot size, $5.3 \mu \mathrm{m}$; working distance, $9.6-10 \mathrm{~mm}$; acceleration voltage, $20 \mathrm{kV}$ ). Ash samples were mounted in aluminium stubs and coated with carbon before the study. Analyses were carried out at the Centres Científics i Tecnològics of the Universitat de Barcelona (CCiTUB), Spain.

The mineralogical characterization was determined by X-ray diffraction (XRD) analysis at the X-ray Diffraction Service of the ICTJA-CSIC. The samples were powdered in an agate mortar and the diffractograms were obtained using a Bruker D-5005 instrument $(\mathrm{Cu}$ K- $\alpha 1$ radiation, $\lambda=1.5405 \AA$, at $40 \mathrm{kV}$ and 40 $\mathrm{mA}$ ), collecting data between 4 and $60^{\circ}$ of $2 \theta$, with a scan step of $0.05^{\circ}$ and a 
step duration of $3 \mathrm{~s}$. Diffractogram evaluation was carried out using the EVA software.

Concentrations of major and trace elements in bulk ash samples were determined by high resolution-inductively coupled plasma-mass spectrometry (HR-ICP-MS) using a Thermo Scientific Element $2 \mathrm{XR}$ at the labGEOTOP of the ICTJA-CSIC. Analysis was performed on a split $(0.1 \mathrm{~g})$ of each sample (9 samples). Before the acid attack, the samples were dried for 24 hours at $40^{\circ} \mathrm{C}$ and then digested with $\mathrm{HNO}_{3}: \mathrm{HF}: \mathrm{HClO}_{4}(2.5: 5.0: 2.5 \mathrm{ml}, \mathrm{v} / \mathrm{v})$, and doubly evaporated to incipient dryness with the addition of $1 \mathrm{ml}$ of $\mathrm{HNO}_{3}$; the final solution was made up to $100 \mathrm{ml}$ in a volume flask with Milli-Q plus ultrapure water type $(18.2 \mathrm{M} \Omega / \mathrm{cm})$. The precision and accuracy of analytical determinations were monitored using reference materials of the Geological Survey of Japan (andesite JA-2 and basalt JB-3) (Imai et al. 1995). Loss on ignition (LOI) was determined by heating $0.5 \mathrm{~g}$ of sample at $1000{ }^{\circ} \mathrm{C}$ for a minimum of 4 hours. Some LOI values appeared negative due to iron oxidation (Lechler \&Desilets 1987).

Blott SJ, Pye K (2001): GRADISTAT: A grain size distribution and statistics package for the analysis of unconsolidated sediments. Earth Surface Processes and Landforms 26, 1237-1248

Blott SJ, Croft DJ, Pye K, Saye SE, Wilson HE (2004): Particle size analysis by laser diffraction. Geological Society, London, Special Publications 232, 63-73

Imai N, Terashima S, Itoh S, Ando A (1995): 1994 compilation values for GSJ reference samples, igneous rock series. Geochemical Journal 29, 91-95

Lechler PJ, Desilets MO (1987): A review of the use of loss on ignition as a measurement of total volatiles in whole-rock analysis. Chemical Geology 63, 341-344 